\title{
A STUDY OF THE USE OF A GUIDE TO SCHOOLWIDE PLANNING FOR TEACHER AIDE SUPPORTS IN A NEW ZEALAND PRIMARY SCHOOL
}

by

Mary Philomena Hancox

A thesis

submitted to the Victoria University of Wellington in fulfilment of the requirements for the degree of Master of Arts in Education

Victoria University of Wellington 2004 


\begin{abstract}
This study chronicled a process of schoolwide planning for teacher aide supports in a New Zealand primary school. The process replicated the work of Giangreco, Edelman and Broer and followed the guidelines set out in their work - A Guide to Schoolwide Planning for Paraeducator Supports (Giangreco, Edelman, \& Broer, 2001a). Data reflect the utilisation and outcomes of the process by school personnel and by the voluntary school team, which was made up of representatives from all adult constituencies of the school community, that is, management, teachers, teacher aides and parents. Results indicated that the process assisted the school and the team in self assessing their teacher aide practices, identifying priorities in need of improvement and developing action plans. Some logistical difficulties were encountered in the implementation of these plans, but despite these difficulties, the team reported a high level of satisfaction with the process. They reported that the process did what it purported to do and rated it highly on consumer-oriented variables (e.g. the logic of the process, ease of use). Additionally, teacher aides responded positively to a questionnaire on the impact of the process on their work and the school team took part in semistructured interviews to document the impact of the process on school personnel and student outcomes. Implications for teacher aide supports for teachers of students with special education needs in regular classrooms are discussed.
\end{abstract}




\section{Acknowledgements}

I am grateful to the many people who have helped and supported me throughout this study. I would like to acknowledge and give my thanks to:

Dr. Michael Giangreco (and his team) at the Center on Disability and Community Inclusion, University of Vermont, for sharing with me the results of the US field studies and for assisting me with the adaptation of the guide. His advice and encouragement in the early stages was really valuable. I hope that my study will add to the research in this field.

Victoria University of Wellington - especially Charlotte Thomson who was my supervisor throughout this study - for all the advice, guidance and support. Thankyou also to the library and learning support staff.

Christchurch College of Education for the research grant in the first year of the study and to Carol Saysell in the College Library for the many searches done for material for the literature review.

The members of the Teacher Aide Support Team, without whom this study would have been impossible, for their commitment to the study and the extra time generously given.

The Rotary Club of Ferrymead, Christchurch, for their donation to the participating school to cover administration costs for the study.

My RTLB colleagues in the Aranui cluster, for all their encouragement and support - it was very much appreciated.

Christine Woodside for all her IT knowledge and assistance in putting it all together. Her calm expertise was invaluable.

Family and friends who have listened and encouraged, sympathised and advised, cooked and shopped and generally supported me throughout the last two years. Many thanks to you all. 


\section{TABLE OF CONTENTS}

Abstract

Acknowledgements

Table of Contents

List of Tables vi

List of Appendices vii

$\begin{array}{ll}\text { Introduction } & 1\end{array}$

CHAPTER ONE 3

Inclusion 3

New Zealand Context 3

Inclusive Education 6

Teacher Aides in Inclusive Schools $\quad 7$

Models of Inclusion 8

Collaboration, Teamwork and a Shared

Summary 10

CHAPTER TWO 12

Teacher Aides $\quad 12$

Definition of Teacher Aides 12

Characteristics of Teacher Aides 12

The Role of the Teacher Aide 14

Historical 14

New Zealand Context 14

Changing Role 15

Teacher Aide Training 19

Teacher Aide Supervision 22

Summary 25

CHAPTER THREE 26

The Guide 26

Development of The Guide 26

Trialling of The Guide 27

Structure and Content of The Guide 30

The NZ Guide 33

Research Questions 34

CHAPTER FOUR

Methodology 35

Data Collection Methods and Sources 35

Data Analysis 37

Research Questions 38

Procedures 39

Step 1. Communication with Board

of Trustees 
Step 2. Selection of Appropriate TAST Members

Step 3. Self-assessment of School Status of Teacher Aides Indicators

Step 4 Prioritisation of Indicators that Reflect School Needs

Step 5 Communication with Board of Trustees and School Community

Step 6 Creation of Action Plans to Address Schools Prioritised Needs

Step 7 Identification of Relevant Resources 49

Step 8 Implementation of Action Plans 50

Step 9 Evaluation of Impact of Plans 50

Step 10 Communication of Impact to School Community

CHAPTER FIVE

Results

1. How does the school rate itself on the 28 indicatorsof teacher aide support?

2. What are the school's self-identified teacher aide priorities?

3. What actions does the school take to address its teacher aide priorities?

4. What do team members rate the teacher aide planning process on whether it did what it purported to do, and consumer variables?

5. What are participants' perspectives on the strengths, weaknesses and suggestions for improving the teacher aide planning process?

6. What impact does the teacher aide planning process have on personnel and students?

CHAPTER SIX

Comparison with the US Study 68

Action Rankings

69

Priorities versus Actions $\quad 70$

Implementation of Plans 73

Limitations 74

Conclusions and Implications $\quad 74$

$\begin{array}{ll}\text { References } & 77\end{array}$

$\begin{array}{ll}\text { Appendices } & 83\end{array}$ 


\section{List of Tables}

Table 2.1. Schools' views of roles of teacher aides/kaiawhina. 24

Table 4.1. Sources of data and personnel involvement for each 38 research question.

Table 4.2. Brainstormed ideas for Priority One with ratings based on a set of determined criteria.

Table 4.3. Brainstormed ideas for Priority Two with ratings based on a set of determined criteria.

Table 5.1. Self-assessment results of indicators of teacher aide supports.

Percentages for each constituency and overall percentages.

Table 5.2 Priority ranks, and self assessment ratings based on indicators of teacher aide support.

Table 5.3. The six indicators of teacher aide support with the highest overall combined "needs major work" and "needs some work" percentages.

Table 5.4. The six indicators of teacher aide support with the highest overall combined “ok for now” and “doing well” percentages.

Table 5.5. Teacher aides' ratings - highest combined "needs major work” and "needs some work" percentages.

Table 5.6. Teacher aide's ratings - highest combined "ok for now" and “doing well” percentages.

Table 5.7. Teacher aide responses to questionnaire. 


\section{List of Appendices}

Appendix A

Appendix B

Appendix C

Appendix D

Appendix E

Appendix F

Appendix G

Appendix $\mathrm{H}$

Appendix I

Appendix J

Appendix K

Appendix L

Appendix $\mathrm{M}$

Appendix $\mathrm{N}$
Self-assessment Survey

Brainstorming Worksheet

Plan of Action Outline

Individual Team Members’ Questionnaire

Teacher Aide Questionnaire

Semi-structured Interview

Guidelines for “Teacher Only” Day

Meeting

Orientation Checklist

Learning Support Plan

Participant Information Sheet

Participant Consent Form

Plan of action (1)

Plan of action (2)

Plan of action (3) 


\section{Introduction}

There has been a dramatic increase in the past decade, not only in the number of teacher aides working in New Zealand schools, but also in the key roles that they undertake (AC Nielson, 2001). The roles range from providing one to one assistance with students with physical, learning and/or behavioural needs, through liaising with outside agencies to making morning tea in the staffroom.

In my work as a Resource Teacher Learning and Behaviour (RTLB) and as a Project Developer on a teacher aide professional development programme - Kia Tutangata ai Supporting Learning (New Zealand Ministry of Education, 2002), I became increasingly aware that this teacher aide resource may not be being used to best advantage for the support of students with special education needs in regular classrooms or their teachers. I was therefore interested in examining how schools might be helped to optimise this valuable and costly resource.

Whilst it is important to address the training needs of teacher aides, we need to be mindful that doing this without considering strengthening the roles, responsibilities and working conditions of the classroom teachers and specialists, we may be sanctioning the least qualified personnel in a school, typically the teacher aides, to assume ever greater responsibilities for students with the most complex and significant learning and behavioural challenges (Brown, Farrington, Knight, Ross \& Ziegler, 1999; Giangreco, Broer \& Edelman, 1999). Therefore, an examination of teacher aide support for teachers of students with special education needs is timely. This support needs to be considered within the wider context of school improvement, where teacher aide support is not the only solution to improving educational opportunities for these students, but one among many options and combinations.

A review of the current literature identified the importance of the work of Dr. Michael Giangreco and his team at the Center on Disability and Community Inclusion, University of Vermont. I considered that the guide (Giangreco, Edelman, et al., 2001a) they had developed for schoolwide planning for teacher aide support would be a useful tool for schools in New Zealand and so with the permission and assistance of the authors, I adapted the guide. This study outlines the field testing of the New Zealand guide in one New Zealand primary school. 
This dissertation begins with a review on the themes and issues that are emerging in current literature on inclusion and in particular, teacher aides working in inclusive schools (Chapters $1 \& 2$ ). It goes on to outline the planning process (Giangreco, Edelman, et al., 2001a) and the field tests (Giangreco, Broer, \& Edelman, 2001a; Giangreco, Edelman, \& Broer, 2003) carried out in the US by the original authors (Chapter 3). The New Zealand case study follows with the methodology and results reported (Chapters $4 \& 5$ ) and discussed in the final chapter (Chapter 6).

Ethical approval for this study was applied for, and given, by the Ethics Committee at Victoria University of Wellington, New Zealand. 


\section{CHAPTER ONE}

\section{Inclusion}

\section{New Zealand Context}

Special Education 2000 (Ministry of Education, 1996) outlines special education policy in New Zealand. It has as its overall aim “...to achieve, over the next decade, a world class inclusive education system that provides learning opportunities of equal quality to all students” (p.5). Special education policy is in keeping with the reforms in the administration of education in New Zealand since 1989 with Tomorrows Schools (Lange, 1988). It is similar to reforms undergone in many other countries and gives a clear direction towards inclusion.

New Zealand schools are able to use their educational resources as they determine, within overall guidelines set by the Minister of Education. Schools are run as partnerships between the professionals and the particular communities in which the schools are located. Boards of Trustees, with governance responsibilities, are the mechanism for this partnership. Schools set their own objectives within the overall guidelines determined by the Minister and within the context of the national curriculum. These objectives are intended to reflect the particular needs of the communities and are set out in the schools' charters, which act as a contract between the schools and their communities, and between the schools and the Minister (Mitchell, 1999).

New Zealand schools are obligated, under these reforms, to include the following goal in their school charter.

To enhance learning by ensuring that the school's policies and practices seek to achieve equitable outcomes for students of both sexes; for rural and urban students; for students from all religions, ethnic, cultural, social, family and class backgrounds and for all students irrespective of their ability or disability. 
Mitchell (cited in Fraser, Moltzen, \& Ryba, 2000) writes that schools also have responsibilities towards students with special education needs under Section 8 of the Education Act 1989, which states “people who have special education needs (whether because of disability or otherwise) have the same right to enrol and receive education at state schools as people who do not” (p.32).

One of the components of the National Education Guidelines (NEGs) (Ministry of Education, 1997), to which all New Zealand schools must adhere, are the National Administration Guidelines (NAGs) which are guidelines relating to school administration. They include the setting out of statements of desirable conduct or administration for “specified personnel or bodies” (p.2). The NAGs require that Boards of Trustees, through the principal and staff, identify students and groups of students who are not achieving, who are at risk of not achieving, or who have special needs (Revised NAG 1 (iii)).

The New Zealand Curriculum Framework (Ministry of Education, 1993), which is the foundation policy statement covering teaching, learning and assessment for all students in New Zealand schools, contains the following statement that is of particular relevance to students with special education needs.

The school curriculum will recognise, respect and respond to the educational needs, experiences, interests and values of all students; both male and female students, students of all ethnic groups; students of different abilities and disabilities; and students of different social and religious backgrounds. Inequalities will be recognised and addressed. All programmes will be gender inclusive, non racist, and non discriminatory, to help ensure that learning opportunities are not restricted (Ministry of Education, 1993, p.7).

The Special Education Policy Guidelines (Ministry of Education, 1995) were published, with minor revisions in 1999 (Ministry of Education, 1999). These were built around certain principles that had implications for school practice. These principles encompassed the rights of students with special education needs to high quality education from the time of identification through to post school options. The guidelines emphasised the focus of special education on meeting needs and having equitable access to resources. They underlined the importance of family and whanau (wider family) involvement in choice and 
in overcoming barriers to learning. They also stressed the importance of language and culture in the learning and development of students.

The policy guidelines were written for all personnel involved with learners with special education needs in early childhood and school sectors. They fit within the context of relevant New Zealand government legislation, education regulations and policies. The Special Education 2000 (SE 2000) Policy framework for schools was presented by the New Zealand Ministry of Education to the education sector as a pyramid. The apex represented resources for students with high to very high needs. These are students with high sensory, physical and health needs, severe speech language needs and students with severe behavioural difficulties who qualify for the Ongoing Reviewable Resourcing Scheme (ORRS). Some teacher aides are employed to assist with these students.

The next layer of the pyramid represented the resources for students with moderate sensory, physical and health needs as well as students with moderate learning and behaviour needs. These resources include the complementary initiatives of the Resource Teachers of Learning and Behaviour (RTLB) and the Special Education Grant (SEG). It is from the SEG that most schools employ their teacher aides.

Teacher aides are often viewed by schools and communities alike, as being the prime solution to the challenge of including students with special education needs in their local schools and it follows, therefore, that the main expenditure of the special education grant continues to be teacher aide hours (Wylie, 2000).

The final layer of the pyramid was given over to resources for early intervention in the early childhood sector. These resources included teacher aides - known as education support workers. The whole pyramid was encompassed by provision for equipment, transport, professional development and training, research, monitoring and evaluation.

The move to inclusion was recognised in the underlying philosophy of the Kia tutangata ai programme - a New Zealand Ministry of Education initiative for teacher aides/kaiawhina (Ministry of Education, 2002). The programme emphasised that current thinking places importance on an ecological approach to intervention. It advocated that both the teacher aides supporting teachers with students with special education needs in 
their classrooms and the teachers themselves have a unified focus within a positive working environment, with inclusion as the long term goal (Couper, 2003).

\section{Inclusive Education}

The concept of inclusion is part of a broad human rights agenda that argues that all forms of segregation are morally wrong. United Nations policies affirm the rights of all children to be valued equally, treated with respect, and provided with equal opportunities within a mainstream education system (Avramidis, Bayliss, \& Burden, 2000). Ballard and MacDonald (1998), in their contribution to an international study of inclusion in education, define inclusion as "processes of increasing the participation of students in, and reducing their exclusion from, mainstream curricula, cultures and communities” (p.2). It can be argued, however, that inclusion encompasses more than simply including students with disabilities in mainstream settings. It is essentially participation for all (Booth \& Ainscow, 1998). As Giangreco, Baumgart and Doyle (1995) state, "Inclusion is much more than a place, rather, it represents a set of values...from which educational decisions are made” (p.275).

Karagiannis, Stainback and Stainback (1996) describe an inclusive education system as referring to a set of beliefs and practices that shift the focus from the diagnosis of individual deficit to the evaluation of instructional adequacy - from the functional limitations paradigm to the ecological paradigm. The ecological paradigm encompasses a system where both the individual and the environment are scrutinised for the "goodness of fit" that exists between the student's instructional needs and the instruction that is offered within the learning environment (Ysseldyke \& Christensen, 1993). This shift has led to a new way of thinking about special education (McLesky \& Waldron, 1998; Skrtic,1995), the use and type of assessment data collected, and the nature of service delivery systems.

Inclusionists believe that all students should be in their local, regular schools and that those schools should alter, adapt and improve to meet their needs, with regard to all aspects of the environment - physical, social and instructional (Thomson, 1998). They believe equity means that, despite our differences, we all have the right to be fully included and that students do not have to reach some stated level of "normality" before being allowed to learn alongside their peers (Ferguson, 1995). 
The concept of normalization (McLesky \& Waldron, 1998) is advocated by the inclusionists. Normalisation in the context of inclusion means that on the one hand disabilities are seen as a normal aspect of diversity and on the other, that students with disabilities are leading as normal a life as possible alongside their peers (Ballard \& MacDonald, 1998). The functional limitation paradigm does not lend itself to either of these aspects of normalisation, so students could perceive themselves and be perceived by others as being different and needing different teachers, different programmes and even, in some situations, different schools (Karagiannis et al., 1996).

An argument put forward by traditionalists is that social skills and social interaction are taking priority over academic learning for students with disabilities, and that the student has a right to access special academic programmes (Kauffman, 1993). However, inclusionists believe that social integration is part of the appropriate education for students with disabilities. Sapon - Shevin (cited in O’Neill, 1995) claims, “I have never ever met a parent of a child with disabilities who did not hope that that child would someday have friends and connections with the broader community” (p.84).

Alongside the shift in paradigms is the view that learning is now usually conceptualised in the literature as an interactive and contextualised process (Will, cited in Moore et al., 1999). Therefore students with special education needs, just like all students, are more likely to learn effectively if they are amongst their same age peers in regular education settings. Effective use of teacher aide support can enhance students' learning experiences in an inclusive school.

\section{Teacher Aides in Inclusive Schools}

The change in attitude and practice from the functional limitation paradigm to the ecological paradigm requires a change in the role of the teacher aide in schools. When the teacher aide support is seen to be needed to help fix the problems within the student, that remedial support is more likely to be focussed on the individual student in a one to one situation (possibly withdrawn from peers). Whereas when teacher aide support is used to assist in changing the environment and reduce barriers to learning so that all students may better access the curriculum and interact with their peers, that support is more likely to be in the classroom setting working more closely with the teacher. More simply put - when 
the shift in paradigms is effective, the teacher aide becomes an aide to the teacher as opposed to an aide to the student.

An inclusive school, according to Clark, Dyson, Millward, and Robson (1999), differs from a non inclusive school not just in its commitment to the philosophy of inclusion but also in its internal structures and practices. These structures and practices move a school from the theory and ideals of inclusion to an attainable reality and might include such structures and practices as an adapted curriculum, collaborative teamwork and socially interactive teaching strategies.

\section{Models of Inclusion}

Successful models of inclusion in the US, according to Lipsky (2003), include such structures and practices as: support for the teacher of students with special education needs (similar to RTLB in New Zealand), special educators taking responsibility for adapting materials and instruction for teachers, including a special educator in a syndicate and whole staff responsibility for all students. Lipsky also identifies some best practices of inclusive classrooms as being: cooperative learning, curricular adaptation, cross-age and peer tutoring and teacher aides allocated to classrooms as opposed to individual students.

In New Zealand, one of the essential requirements of the SE2000 policy was that the Resource Teachers of Learning and Behaviour (RTLB) take a pivotal role in the establishment of inclusive education. These teachers were to provide support for students who "are at risk of low achievement due to learning and/or behaviour difficulties; and their teachers” (Ministry of Education, 1999, p.33). This was reflected in the training that they received at graduate and post-graduate levels (Thomson, Brown, Jones \& Manins, 1999). There were five major themes in the training to ensure that the RTLB were equipped for this role. These were: collaborative consultation as a model of problem solving in service delivery, focus on inclusive teaching philosophy and practice, ecological assessment and intervention, acknowledgement of Maori cultural values and preferred practices, and the encouragement of RTLB to become reflective practitioners. 


\section{Collaboration, Teamwork and a Shared Understanding}

In schools that are working towards inclusion, there is an emphasis on collaboration between all constituencies involved (Friend \& Cook, 2000; Idol \& West, 1991; Villa, Thousand, Nevin, \& Malgeri, 1996). Whole school approaches to inclusion require all staff to share responsibility for meeting the needs of all students. Teachers in inclusive schools report that collaboration is a powerful means of personal and professional development (Lipsky, 2003). Amongst the benefits stated are: reduction of teacher isolation, sharing responsibility for teaching a range of diverse learners, learning new skills and approaches, reflection on practice and added enjoyment to teaching.

The more often that school personnel are able to collaborate the more likely they are to develop flexible problem solving strategies which will enable them to respond appropriately to the diversity of learners in their classrooms. This in turn improves the quality of teaching and learning for all students (Friend \& Cook, 2000).

In order for collaboration to be effective it needs to meet certain criteria. It should first and foremost be voluntary in nature and be based on a shared vision and mutual goals. The participants should have parity and share the responsibility for participation, decision making, resources and accountability for outcomes (Friend \& Cook, 2000). "What is increasingly recognised is that the development of a sense of professional community leads to better outcomes for students and satisfaction and support for educators” (p.13).

The importance of school communities developing a set of shared beliefs, values and principles is emphasised by Giangreco, CichoskiKelly, et al., (1999).

Having a shared understanding provides a basic structure within which teams develop common goals, determine actions that will lead towards the attainment of their goals, ensure that their actions are consistent with their beliefs and judge whether their efforts have been successful. (p.21)

Therefore a shared understanding is a statement of what is aspired to rather than what currently is. It is the initial step and must be followed by effective planning, implementation and evaluation. 
Teacher aides, ideally, should be part of educational teams that can be student, group, class or programme centred. Doyle (2002) states, "It has been my experience that when team members - specifically paraprofessionals, are provided with the basic strategies for organising themselves and for supporting the instruction of diverse students, the quality of instruction for all students improves” (p.xii).

The inclusion of teacher aides in the teaching team is not generally happening in New Zealand schools. According to the mid year report on the New Zealand Ministry of Education teacher aide professional development programme, Kia Tutangata ai Supporting Learning, “There is rarely any expectation that teacher aides/kaiawhina will contribute to the corporate life of the school or work in teams with teachers" (Cameron \& Wylie, 2002). There is evidence, too, that in New Zealand, low priority is given to release time for collegial consultation, planning meetings or training (Kavermann \& Bourke, 1998). Cameron and Wylie (2002) noted, “Teacher aide contracts typically specify face to face work with students only, with no paid provision for preparation or meetings with teachers. This is likely to be a significant barrier . . . unless this issue is specifically addressed” (p. 44).

Wadsworth and Knight (1996), in their checklist for fostering team collaboration, put the number one priority as scheduling weekly meetings for teachers and teacher aides. French and Pickett (1997) point out that when professionals begin to recognise that supervising teacher aides is an important part of their work, then they will begin to solve the problem of when to meet. They give examples of teams who have solved this problem by electing to pay for teacher aides to attend meetings and teams who use a flexible schedule, such as teacher aides coming early or staying late for meetings and compensating on other days.

\section{Summary}

In New Zealand there is a clear direction from policy documents in both general and special education towards an inclusive education system. The move from a functional limitation, deficit oriented paradigm to an inclusive, ecological one has implications for the role of the teacher aide. Inclusive schools require a greater emphasis on collaboration and working towards shared goals. 
In this study an inclusive and ecological approach to teacher aide support was taken. The study promoted collaboration by bringing together representatives from every adult constituency of the school community to form a team whose objective it was to analyse the assessment data, prioritise the topics and design, implement and evaluate plans of action to address these priorities. Teacher aides were represented on the team as equal participants. The collaborative practice promoted in the study involved the voluntary members of the participating school team, including a teacher aide representative, interacting in order to bring about change in the way that the school plans and utilises its teacher aide supports. The team represented a cross section of the adult school community and had the characteristics of an effective team (Giangreco, 1993b). That is, it had two or more members, a shared framework and a unified set of goals. It had members with various skills, who engaged in problem solving and collaborative activities, shared resources, interacted to improve effectiveness and collectively evaluated through feedback. 


\section{CHAPTER TWO}

\section{Teacher Aides}

\section{Definition of Teacher Aides}

There are numerous definitions of teacher aides in the literature (Blacock, 1991; Downing, Ryndax, \& Clark, 2000; Jones \& Bender, 1993; Pickett \& Gerlach, 1997), but the following by French (1999) incorporates the salient features of the majority of definitions:

A paraeducator is a person who works in a school in an instructional capacity alongside school professionals and is supervised by the certificated or licensed professionals who hold ultimate responsibility for the student and programmatic outcomes. (p.65)

The term "teacher aide" is used in this study because it is the most common term to describe those personnel working in schools and related services in New Zealand. However teacher aides are also known as education support workers in the early childhood sector and kaiawhina in kura kaupapa Maori (full immersion Maori schools). In the UK they are described as learning support assistants (LSAs) or support staff, and in the USA as paraeducators, paraprofessionals, instructional assistants or educational assistants (Pickett \& Gerlach, 1997).

\section{Characteristics of Teacher Aides}

American demographics indicate that teacher aides, on the whole, are predominantly female with an average age of 40 years. They usually reflect the cultural, ethnic and socio-economic makeup of the community in which the school is situated and have often come into the role after experiencing the work through their own children, volunteering their services as parent helpers (French \& Gerlach, 1999). 
In New Zealand, Ministry of Education figures (AC Nielson, 2001) indicate that 93\% of teacher aides are female, 73\% are NZ European, 13\% are Maori, 4\% are Pasifika with the remainder classified as “other”. Kaiawhina in kura kaupapa Maori are always Maori, specifically employed to share their cultural and language expertise and experience. There are variations in the number of teacher aides per school, according to region and socio- economic makeup of the school community. There are no data relating to the age of the teacher aides. However, according to a survey (New Zealand Educational Institute, 1995), “The picture is of a group of employees who are largely female, Pakeha/European, with 75\% aged between 30 years and 50 years and having worked in support staff positions for four or more years. Most work part time” (p.10). The NZEI figures, however, also include other support staff such as office staff and library assistants.

French and Chopra (1999) report that parents describe teacher aides as "kind, gentle and caring” (p.264). French (1999) states that classroom teachers have described them as "good, caring, flexible, cooperative, imaginative people, very dedicated to their work" (p.66). She goes on to say that special education teachers have described the “commitment and involvement” (p.66) shown by teacher aides and that teacher aides themselves claim that they are "creative, energetic, flexible, and willing to try almost anything” (p.66). Wadsworth and Knight (1996) offer the following observations regarding the characteristics of teacher aides:

Paraprofessionals frequently are very dedicated individuals who are grossly underpaid. Although some paraprofessionals may aspire to be teachers, often they are unable to pursue this goal because of time, personal, family and financial barriers. Some paraprofessionals...welcome the new challenges and opportunities to learn new skills. (p.166)

The work is particularly attractive to women because it provides an income whilst fitting in with family life, i.e. the same hours and same holidays as their school aged children (French, 1999). The fact that no academic qualifications are needed also attracts those who simply need a job (Rutherford, 2002). 


\section{The Role of the Teacher Aide}

Historical Role

The historical role of teacher aides in New Zealand is similar to that of teacher aides in other countries. They were originally employed during the post war era as one solution to teacher shortage in a fast growing school population. Advances in medical science also meant that students with high needs were surviving infancy and being educated whereas previously they had been considered as ineducable (Pickett, 1999), thus placing demands on local schools to meet the educational needs of these students. The employment of teacher aides was seen to be the solution to this educational crisis (Rutherford, 2002).

The teacher aide's role, originally, was to perform clerical, housekeeping and monitoring tasks (Jones \& Bender, 1993). Teacher aides were also utilised, and still are, for the physical and personal care of high needs students (Boomer, 1994). In the fifties, an American research project by Cruickshank and Haring (cited in Rutherford, 2002) suggested that the teacher aide was to help with administrative tasks allowing the teacher time "to increase the quality of instruction for a greater number of exceptional children who are now being educated in overcrowded special and regular classrooms” (p.14). Thus, originally, the role was seen as one of aiding the teacher rather than as aiding the student.

\section{The New Zealand Context}

In New Zealand, from the late 1950s to the mid 1970s there appears to have been an implicit contract between regular and special education (Moore et al., 1999), where “Those in regular education would support special education in gaining resources and staffing. In return, those in special education would take over the troubled and troublesome students from regular classes” (p.7). It was not until 1987 that there was official ratification of a policy of mainstreaming (Department of Education, 1988). In 1989 this was mandated with the passage of the New Zealand Education Act which entitled all students to a free education from ages 5-19 years at any state school. The inclusion of students with special education needs in regular classrooms led to further growth in the employment of teacher aides in schools. 
There have been changes in education policies through Tomorrow's Schools (Lange, 1988) and SE 2000 (Ministry of Education, 1996), and changes in social reform, where there has been a shift towards greater equity for all. The Human Rights Act (1993) in New Zealand, acknowledged that race, gender, and ability were not grounds for discrimination, including exclusion from mainstream education (Moore et al., 1999).

Alongside the shift in values towards greater equity for all has been the shift in the theorising and understanding of the processes involved in learning, as mentioned in the previous chapter. Learning is increasingly conceptualised in the literature as an interactive and contextualised process (Will, cited in Moore, et al, 1999). Intervention, therefore, is changing from the individual remedial model, where the causes for school failure were conceptualised as being attributed to some neurological or motivational deficit located within the individual, towards a more ecological model where the environment, both social and physical, is recognised as a powerful determinant of learning and behaviour.

\section{Changing Role}

Changing the environment of the student has included the addition of more teacher aides in classrooms and changes in their roles and responsibilities. Along with the expansion in teacher aide numbers has come an expansion in the role of the teacher aide from “teacher helper” (Jones \& Bender, 1993), to working alongside teachers and other professionals in assisting with the delivery of instructional and other direct services to students (Downing et al., 2000; French \& Gerlach, 1999; Giangreco \& Doyle, 2002; Pickett \& Gerlach, 1997).

According to Pickett (1999):

The duties of teacher aides are no longer limited to record keeping, preparing materials, monitoring students in lunchrooms and study halls or maintaining learning centres and equipment. Today they are active participants in the instructional process and the delivery of other direct services to learners and/or their parents. (p.2) 
Under the direction and supervision of teachers, teacher aides instruct learners in groups or individual settings, assist with functional assessment, administer standardised tests, document learner performance, share relevant information with teachers and participate in programme planning teams (Moshoyannis, Pickett \& Granick, 1999).

French and Gerlach (1999) point out that fulfilling the above roles should be the shared responsibility of teacher and teacher aide. They also add to the above: locating, arranging or constructing instructional material, supervising in the playground, assisting students using adaptive equipment, participating in evaluation and feedback, participating in training and coaching sessions, communicating with teachers regarding their work and contributing to the team.

French (1998) identified two central and different perspectives of the teacher aide role held by teachers. The first viewed the teacher aide as an "aide to the student" whilst the second viewed the teacher aide as an "aide to the teacher". If teachers viewed the teacher aide as an aide to the student, they felt uncomfortable in allocating any tasks not directly related to the student. Teachers also preferred to see the aide as a peer rather than a supervisee. French maintained that it was important that there was clarity in the differing roles of teacher and teacher aide, that there could not be equality or parity, just as "the nature of a paramedic's role precludes parity with the emergency room physician” (p.365). She pointed out that the notion of the teacher aide as an aide to the student also meant that teachers were ultimately not acknowledging their ethical and legal responsibilities towards students with special education needs or towards the teacher aide.

Giangreco and Doyle (2002) raise important issues regarding the perspective of the teacher aide as an aide to the student. They query the concept of using untrained personnel as a major model of service provision for students with special education needs. They question the appropriateness, ethics and effectiveness of the least qualified employees being primarily responsible for students with the most complex challenges to learning, whilst students without special education needs receive most of their instruction from qualified teachers.

Wylie (2000) raises some of the same issues. She points out that schools are trying to cope in a way that almost denies the special needs of some students. Simply placing 
teacher aides with students who have special education needs does not solve the problem and in some cases leads to greater dependence than if the student was in a special unit. She also points out the imbalance of having the least trained personnel working with some of the most difficult students.

Another issue associated with using the teacher aide as an aide to the student is the possibility of isolating the student due to the proximity of the teacher aide. This is borne out by findings in a range of studies (Brown et al., 1999; Freschi, 1999; Giangreco, Edelman, Evans-Luiselli, \& MacFarland, 1997). Proximity issues can lead to unintended harmful effects such as interference with ownership and responsibility by regular teachers, separation from classmates, interference with peer interactions, limitations on receiving competent instruction, over-dependence on the teacher aide, gender identity and loss of personal control (Giangreco et al., 1997; Marks, Schrader \& Levine, 1999; Shukla, Kennedy \& Cushing, 1999). Teacher aides, too, can have a feeling of responsibility towards "their" student. They feel that they must ensure that the student is not a "bother" to the teacher, that they must make "on the spot" adaptations to the curriculum and that they are the "expert” on the student (Marks et al., 1999).

It is only within the past decade that these issues of the utilisation of teacher aides, as an aide to the student, have been raised, (Brown et al., 1999; Freschi, 1999; Giangreco et al., 1997; Marks et al., 1999). This recent literature consistently refers to the dedication, commitment, skills and creativity that most teacher aides bring to their work and are at pains to point out that research into better utilisation of teacher aides stems from a desire for better outcomes for students and better working conditions for teacher aides. Too many teacher aides are inadequately appreciated, compensated, orientated, trained and supervised (Doyle, 2002; Giangreco, Edelmann, Broer, \& Doyle, 2001c; Jones \& Bender, 1993; Pickett \& Gerlach, 1997).

Teachers who viewed the teacher aide as an "aide to the teacher" (French, 1998) described the teacher aide as being able to help them meet the students' needs, teach the students exactly the way the teacher wanted them taught, be patient, get all the paperwork done and be able to fill in the gaps. These teachers stated that the teacher aide helps students to meet their goals and objectives that have been written by the teacher (and specialists). The teachers with this perspective had no problem with the 
notion of the teacher aide preparing materials, running off copies, typing minutes or any other tasks which assisted teachers in doing their job as effectively as possible.

The importance of clarifying the differing roles of teacher and teacher aide is emphasised by many authors and is central to a successful partnership. Safarik (1997) summarised the teacher's role as the major decision maker for the instructional objectives for all students after careful assessment and consultation, supervising the implementation of programmes in conjunction with the teacher aide and evaluating the effectiveness of those programmes.

Identifying teacher roles and responsibilities should help to clarify the roles and responsibilities of the teacher aide. According to the non data-based literature of the past decade (Giangreco, Edelman, et al., 2001c), the teacher aide roles and responsibilities ideally should be: (a) providing instruction in academic settings, (b) teaching functional life skills, (c) teaching vocational skills, (d) collecting and managing data, (e) supporting students who exhibit challenging behaviours, (f) facilitating interaction with peers who do not have disabilities, (g) providing personal care and (h) engaging in clerical tasks.

Rutherford (2001) points out that the difference between the above roles and responsibilities and those actually documented in the data based literature pose a contentious ethical issue that needs to be resolved if students with disabilities are to receive a quality education. The data based literature showed the teacher aide roles and responsibilities to include: (a) student testing and assessment, (b) lesson planning, (c) design of learning activities, (d) decisions on the extent and nature of instruction, (e) adaptation and modification of curricular materials and activities, and (f) communication and interaction with families. Teacher aides are often involved in the delivery of specialist services such as speech language therapy, physiotherapy and occupational therapy (Pickett, 1999) and acting as a bridge between the specialists and the students’ school personnel and families (Wadsworth \& Knight, 1996).

Rutherford (2002) suggests that lack of clarity surrounding the roles and responsibilities of teachers and teacher aides could arise from a number of causes, including: 
... lack of training for teacher aides and teachers (regarding the role and supervision of the former), the lack of identity of teacher aides (who seem almost to have entered the education system through "the back door”), and the lack of time provided for regular communication, meetings, planning and supervision. (p. 37)

In New Zealand, the Ministry of Education (2002), in its introductory resource for teacher aides, has clearly identified that the teacher aide is a support and aide to the teacher. It clearly states:

Teachers have prime responsibility for the education of all students in their class, i.e. the planning, provision, monitoring and evaluation of learning. Teacher aides/kaiawhina work under the supervision of a teacher and in accordance with defined school procedures to support teaching programmes and student learning. (p. 5)

\section{Teacher Aide Training}

Doyle (2002) stresses the need for training for teacher aides. "The complex and evolving nature of the paraprofessional's role and the importance of paraprofessionals in the lives of children and adolescents in inclusive classrooms makes introductory and ongoing training and supervision necessary” (p.3).

Pickett (1996) states that teacher aides should more accurately be described as paraeducators just as their counterparts in medicine and law are designated as paramedics and paralegals. Clark et al. (1999), argue however that, unlike paramedics and paralegals, teacher aides require no qualifications to be eligible for their employment. This is certainly the case in New Zealand where $60 \%$ of teacher aides employed in schools have no relevant qualifications (AC Nielson, 2001).

In a literature review on teacher aide training programmes in the United States (Morgan, Hofmeister, \& Ashbaker, 1995), little consensus on course content was found. Lack of consensus could be a reflection of the fact that there is confusion regarding the role of the teacher aide. The topics that occurred most often were behaviour management and 
monitoring, assessment and evaluation. The authors considered that these topics reflected the changing role of teacher aides in education. However it appears that there are certain core topics generally covered in teacher aide training and additional specialist topics depending on the setting in which the teacher aide is working (Doyle, 2002; Fraser, et al., 2000; French, 1998; Morgan et al., 1995; Pickett \& Gerlach, 1997; Rutherford, 2002; Thorburn, 2001; Wallace, Bernhardt, \& Utermarck, 1999).

In New Zealand, the Ministry of Education funded training programme - Kia Tutangata ai - Supporting Learning (Ministry of Education, 2002) was developed for schools with teacher aides who have little or no specific qualifications for their work supporting teachers of students with special education needs. It consists of a video with supporting printed material. Initially it was delivered by facilitators employed by the Ministry of Education, but it was always intended to stand alone as a resource that could be used independently within schools. The programme explores, with the entire staff of the school, three key themes: (a) roles and responsibilities, (b) team work and, (c) problem solving. Each theme is introduced by the video. A framework is also provided in the resource for discussion on how that theme relates to individual schools, by working through some suggested activities. The programme recognises the importance of whole school involvement in identifying the role of the teacher aide in schools. It promotes a team approach to creating systems within schools that best include and support the work of teacher aides who are an "aide to the teacher” of students who have special education needs in regular classrooms.

After working initially with the whole staff, the training is then focussed on the teacher aides. The programme covers the processes, strategies and resources required for teacher aide work. The choice of processes and strategies included in the training package reflects the recognition of the whole school involvement and a team approach. Examples of the topics included are confidentiality, effective communication, partnership with parents, caregivers and families, fostering friendships, recording skills and IEPs. Strategies to support learning and understanding student behaviour are also included. There is recognition, too, that teacher aides need to be given background information on special education and New Zealand legislation, Te Ao Maori, the Treaty of Waitangi and working with Pacific students. The contract between the New Zealand Ministry of Education and the schools provided workshops for teacher aides, follow-up 
sessions in schools with the facilitators, and training sessions with principals and key personnel.

Whilst it is important to consider the content of teacher aide training programmes, it is equally important to consider how these programmes are delivered. Giangreco, Broer, et al. (1999) recommend that training should combine formal in-service training sessions with on-the-job coaching. Johnson et al (cited in Thorburn, 2001) offer recommendations for the process, delivery and facilitation of teacher aide training. They emphasise communicating the value and importance of teacher aides in the instructional process, incorporating topics requested by teacher aides to meet their professional needs, ongoing responsive support, opportunities for sharing, interacting and problem solving. They add to these: time to let off steam, focussing on best practice, useful strategies, celebrating success and providing opportunities for teachers and teacher aides to train together.

Teachers and teacher aides sharing professional development is a relatively new concept in New Zealand. A few courses are offered by the colleges of education, to which both teachers and teacher aides are encouraged to attend together. Some of the New Zealand Ministry of Education Special Education 2000 Contract offered professional development for teams of teachers and teacher aides. The teacher aide training resource (Ministry of Education, 2002) makes steps in this direction by its emphasis on whole school involvement, teamwork and problem solving.

Teacher aides often experience barriers to training such as cost, lack of employment security, family commitments, accessibility and relevance. A significant barrier in New Zealand is that teacher aide qualifications do not necessarily lead to an increase in income. There is no clear career path for teacher aides although some do go on to qualify as teachers.

Although the effective training of teacher aides would undoubtedly improve the support that they provide for schools, it is important to acknowledge that this alone would be only a "band aid" (Giangreco \& Doyle, 2002). The fundamental questions we should be addressing would remain unanswered. Questions such as the ones mentioned previously by Giangreco and Doyle (2002): 
- Are models of service provision that rely heavily on paraprofessionals to provide instruction to students with disabilities appropriate, ethical, conceptually sound, and effective?

- Does it make sense to have the least qualified employee primarily responsible for students with the most complex challenges to learning?

- Is it acceptable for some students with disabilities to receive most of their education from a paraprofessional, regardless of training level, whilst students without disabilities receive the bulk of their instruction from certified teachers?

Assigning teacher aides to students with special education needs does not necessarily change teacher attitudes, increase the skills of teachers to provide differentiated instruction or ensure that students receive quality instruction (Giangreco, Broer, et al., 2001b).

\section{Teacher Aide Supervision}

The supervision of teacher aides is an important area for development. Many teachers do not feel prepared for the task of supervising another adult. There can be perceptions of inadequacy on the part of the teacher, especially with a teacher aide who is older or more experienced or who is of a different culture, socio-economic group or ethnic background (Salzberg \& Morgan, 1995). Teachers generally do not choose the teacher aides with whom they work and role confusion can hinder a working partnership. Wylie (2000) recommended that pre-service teacher education include a compulsory component relating to the education of students with special education needs. Teacher trainers need to ensure that teachers are able to work collaboratively and in a supervisory capacity with other adults in their classrooms. Professional development opportunities that focus on teachers and teacher aides working as a team will improve outcomes for both school personnel and students. (Doyle, 2002).

Meyer and Bevan-Brown (2000) point out that teacher aide hours are the most common and most requested service from schools in New Zealand for students with special education needs. Wylie (2000), in her report on SE 2000, notes that the main use of the Special Education Grant (SEG) is to provide teacher aide hours. This grant is a lump sum given by the New Zealand Ministry of Education to schools to spend on special education needs as the schools see fit. The grant is a dollar amount per student, based on 
the number of students on the school's roll and the decile rating of the school. Around $\$ 30$ million is spent on the SEG annually.

According to AC Nielson (2001), in a survey of 2,581 New Zealand schools, 78\% $(2,031)$ indicated that they had teacher aides employed in their schools for students who had special education needs, totalling 8,155 teacher aides in all. This is a costly resource. However, teacher aide support of students with special education needs remains "one of the least studied and potentially most significant aspects of special education over the past decade” (Giangreco, Edelman, et al., 2001c, p.45).

As stated earlier, Kia Tutangata ai (Ministry of Education, 2002) promotes a whole school approach which fosters the innovative use of resources, development of teaching strategies and collaborative problem solving. The whole school approach is one where "responsibility is identified and shared, expertise is recognised and valued and opportunities for communication are planned within an environment that encourages positive relationships of trust, open communication and caring” (p.7).

The professional requirements identified for teacher aides in this resource, emphasise the importance of the teacher aide being able to work effectively, flexibly and confidentially as part of a team in partnership with students, teachers, specialists, family, whanau and schools. It goes on to suggest that the role of the teacher aide encompasses working with the team to assist in planning, supporting and recording progress of programmes prepared and supervised by the teacher.

The Ministry of Education acknowledges that there is confusion around the roles and responsibilities of teachers and teacher aides. In a letter sent out in 2001 to all school principals, in preparation for Kia Tutangata ai (Ministry of Education, 2002), it was noted that it was not uncommon for teachers and teacher aides/kaiawhina to experience some confusion about roles and responsibilities especially when they begin working together. The letter stated that clear understanding of roles increases the benefits of teacher aide support for teachers and their students.

Cameron and Wylie (2002) in their mid year evaluation of Kia Tutangata ai (Ministry of Education, 2002), surmised from the staff workshop returns that "the respective roles and responsibilities of teacher aides/kaiawhina and teachers are still unclear in many 
schools, which suggests that schools should benefit from knowledge about more effective deployment of teacher aides/kaiawhina” (p.14). It can be seen in Table 2.1 what the participating schools considered to be happening already in their schools, in regard to the role of the teacher aides.

Table 2.1: Schools’ views of roles of teacher aides/kaiawhina.

Statements
The teacher aide/kaiawhina is
included in systems which provide
information about students and school
activities.
The teacher aide/kaiawhina is
actively involved in IEP meetings and
other meetings between team
members.

There is an integrated system in place comprising job descriptions, appraisal and professional development for the teacher aide/kaiawhina.

The teacher aide/kaiawhina is invited
to attend all staff meetings.

There is a written plan for teachers and teacher aide/kaiawhina to use for supporting learning and to provide feedback.

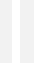

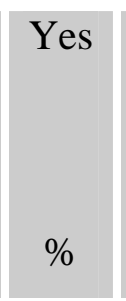

83

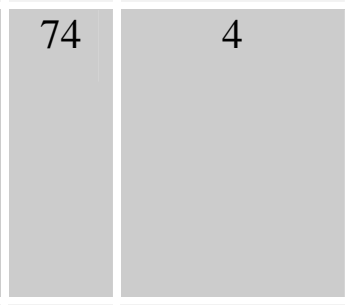

71

6

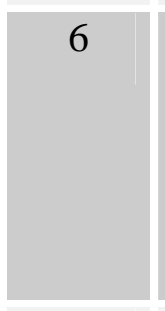

4

Don’t
know/
Unsure
$\%$

4

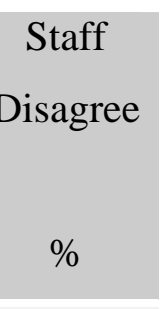

10

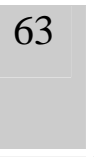

57

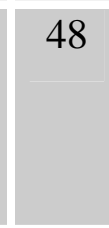

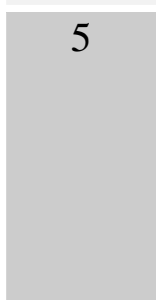

11
10

9

\section{Opportunities are provided for teachers and teacher aide/kaiawhina to plan and evaluate together.}

Source: Evaluation of the introductory professional development programme for teacher aide/kaiawhina supporting teachers of students with special education needs (Cameron \& Wylie, 2002). 
This study expands on these statements in its indicators of teacher aide support generated from a shared understanding about fundamental beliefs, values and principles that guide the work of teacher aides. Rutherford (2001) emphasises that "given that one of the most common issues regarding teacher aide employment is a vagueness about actual roles and responsibilities, it seems crucial that all involved are operating from a shared understanding of the value and nature of teacher aide work” (p.23). Clarification of roles and responsibilities is fundamental to the effective support of students with special education needs. The Guide (Giangreco, Edelman, et al., 2001a) used in this study is a useful tool to aid that clarification.

\section{Summary}

The teacher aide role has shifted from being an aide to the teacher towards being an aide to the student as more students with special education needs are placed in regular classrooms. This has raised legal and ethical questions for schools, highlighting issues regarding proximity, and the importance of effective training and supervision of teacher aides.

This study examined how one New Zealand school approached issues in teacher aide supports. Through a shared understanding of the value and nature of teacher aide supports in the participating school, this study identified key indicators of the ideal of the teacher aide as an aide to the teacher and raised awareness of the value of teacher aides and their contribution to the life of the school. The study assisted in identifying appropriate training needs and professional development opportunities.

The approach taken in this study reflected the major themes of Kia Tutangata ai (Ministry of Education, 2001). The study endeavoured to clarify the support already being given by teacher aides to teachers of students with special education needs in the participating school. It used a team that represented the whole adult school community to assess this. The team problem-solved solutions to areas in need of work, made plans of action to address those needs and implemented and evaluated the actions taken and their impact on the students, staff and community of the school. 


\section{CHAPTER THREE}

\section{The Guide}

Dr. Michael Giangreco and his team of researchers at the Center on Disability and Community Inclusion (CDCI) at the University of Vermont developed and extensively trialled a school based collaborative problem solving process for improving teacher aide supports in schools. They developed guidelines for school personnel to enable them to put the process in place in their particular school. These were published as 'A Guide to Schoolwide Planning for Paraeducator Supports’ (Giangreco, Edelman, et al., 2001a). This is referred to throughout this dissertation as "The Guide".

The purpose of The Guide is to assist school based teams to self assess their status against specified indicators of good teacher aide supports, identify their priorities in relation to those indicators, develop appropriate plans of action, implement those plans and evaluate their impact on school personnel and student outcomes.

\section{Development of The Guide}

The development of The Guide and the indicators of good teacher aide supports it contains were based on the researchers' shared understanding of the nature and value of teacher aide work. This shared understanding grew from a combination of information from educational literature and research and the collective personal experiences of the team of researchers as parents, community members, advocates, paraeducators, teachers, special educators, related service providers, and administrators (Giangreco, CichoskiKelly, et al., 1999).

The authors considered that in order to be effective, school personnel had to develop a shared understanding of underlying beliefs, values and principles that would guide their work together. They defined a shared understanding as a vision, something that is aspired to, rather than what currently is. Having this shared understanding would provide a framework within which school teams could develop shared goals, determine actions to achieve those goals and evaluate their achievements. 


\section{Trialling of The Guide}

The pilot study (Giangreco, Broer, et al., 2001a) was conducted during the 1999-2000 school year in four schools in the same school district. Whilst the results provided positive feedback about the process and led to some constructive action within those schools, the researchers considered the limitations of the study were too significant to allow comment on the general usefulness of The Guide.

A second study (Giangreco et al., 2003), conducted during 2000-2002, was in a larger cross section of schools and also included data about the impact of the process on school personnel and students. The Center on Disability and Community Inclusion (CDCI) at the University of Vermont where the researchers were based, offered schools a US\$1000 mini grant for field-testing the guide. The grant attracted 46 schools across thirteen states.

In the second study there was an average of 14 teacher aides per school. The study addressed the support provided by 652 teacher aides who assisted in the education of 3,461 students who had Individual Education Plans (IEPs).

The team members across the 46 schools numbered 359 of which 331 (92\%) provided data. The 359 were made up of 125 teacher aides, 61 regular classroom teachers, 59 special educators, 27 parents, 36 principals or assistant principals, 12 specialists (e.g. Speech Language Therapists) and 11 "others" - community members, board members, and bus drivers.

Each school was provided with The Guide and was encouraged to be flexible to ensure that the process was relevant and meaningfully individualised for their setting. The teams then used the process to assess their schools' needs, identify priorities, develop plans, and implement and evaluate those plans.

There were three primary sources of data collected and analysed - (1) the planning booklet for team makeup, timelines, self-assessment ratings, priority selections and action plans, (2) a Likert-style questionnaire completed by individual team members concerning the process, plus questions regarding the strengths and weaknesses of the 
process and suggestions for improvement, and (3) written reports from each of the teams on the impact on school personnel and students.

In their findings the authors identified several important limitations. The process was evaluated by its developers; there was no control group; participants were voluntary; there can be no assumption of strict fidelity in the use of the planning process and there was a wide variety of impact reports. However despite these limitations, the study does provide authentic, field-based data which suggests that schools with widely varying characteristics successfully used the planning process, rated it favourably and stated that the implementation of their plans resulted in a wide variety of positive outcomes for their schools.

The findings showed that most teams rated themselves as having to do "major work" or "some work" on the majority of the 28 indicators of teacher aide support. Twenty-one were rated this way by $50-96 \%$ of the schools. The highest needs in these categories were (a) relief teacher aides recruited and trained, (b) orientation and entry-level training, (c) times and mechanisms to work with teachers, (d) on-the-job training to match responsibilities, and (e) compensation for education, experience and skills. All five of these were in the top eight overall priorities selected.

Only seven indicators were rated as "ok for now" or "doing well” by 51-70\% of the schools. The five highest rating were (a) teachers aides carry out a variety of supports, (b) demonstrate constructive interpersonal skills, (c) teacher aides provide important services, (d) professional staff have ultimate responsibility, and (e) teacher aides promote independence for students.

The most frequently identified priorities that needed work were (a) orientation and entry-level training, (b) on-the-job training to match responsibilities, (c) accurate job descriptions, (d) relief teacher aides recruited and trained, and (e) access to ongoing learning opportunities. The five most frequently taken actions were (a) orientation and entry-level training, (b) on-the-job training to match responsibilities, (c) times and mechanisms to work with teachers, (d) accurate job descriptions, and (e) access to ongoing learning opportunities. Therefore four out of five most frequently taken actions were also amongst the top five priorities. 
There were some notable exceptions. For example, relief teacher aides recruited and trained was rated most in need of work and was ranked fourth in priority. However only 5 of the 46 teams took any actions. Similarly compensation for education, experience and skills was ranked as the fifth highest priority but only 2 schools took any action. Whereas times and mechanisms to work with teachers was only seventh on the priority list but jumped to third place when it came to taking action.

It was noted by the authors that schools chose to take actions on what was referred to as "first generation" issues, that is, those considered to be the most basic (e.g., job descriptions, training, orientation). The authors stated that schools were often aware of these issues long before their participation in the field study, but that it took the structured process of The Guide to translate this awareness into action.

Although there was a strong relationship between needs, priorities and actions taken, the data collected in the US study showed that there were factors that influenced the choice of action. These were factors such as perceived ease or difficulty of implementation, time, immediacy of need, and perceived locus of control.

The authors anticipated that when first generation issues had been attended to, then “second generation” issues were more likely to be dealt with. These are issues such as teacher education for supervising teacher aides, developing criteria for assessing the need for teacher aide support and evaluating the impact of teacher aide services.

The impact reported by the schools involved in the field-testing of the US study was influenced by the first generation actions taken. The fact that $79 \%$ of schools reported that teacher aides knew their job better corresponded with the actions taken by the schools. The actions were entry-level training; development of orientation manuals and procedures; and development of job descriptions. The impact on school personnel and students will vary according to the actions taken.

The findings indicated that the process did assist the school teams in self assessing their teacher aide practices, identifying their priorities in need of improvement, developing action plans and implementing them. Individual team members reported that the process did what it purported to do and rated it highly on consumer-orientated variables such as ease of use and whether the process was logical. The data also showed that the 
implementation of the action plans resulted in a wide variety of positive outcomes for school personnel and students.

\section{Structure and Content of The Guide}

At the beginning of The Guide, general directions and tips are outlined for the school team. It is recommended that each team member have their own Guide to use as a workbook to record the meetings, ideas etc, but that one master copy be kept. Suggestions on the frequency of meetings, consultation with peers and use of collaboration when running the meetings are given.

The process is then outlined step by step:

Step 1. Communication with Board of Trustees

Early consultation with the school's Board of Trustees (and any other school or community groups who may be involved and/ or interested) to raise awareness of the importance of teacher aide issues. It is suggested that a rationale be formed to address these issues within the context of overall school improvement.

\section{Step 2. Selection of appropriate team members}

The Guide gives ideas on which constituencies to involve, and alerts the school to try and enlist team members with different experiences. For example, a teacher who has a student with high needs in their classroom as well as a teacher who has students with more moderate needs. It also emphasises that the time commitment, and considerations such as childcare and release time, should be taken into account.

Step 3. Self-assessment of school status on teacher aide topics

Once the team is formed, the next step is to self assess on the 28 indicators that reflect the shared understanding of the authors in regard to teacher aide supports for students with special education needs in regular classroom settings (Appendix A). 
The indicators are set out under six headings (or teacher aide topics). They are:

- Acknowledging

- Orienting and training

- Hiring and assigning

- Interaction with others

- Roles and responsibilities

- Supervision and evaluation

It is the suggestion of the authors that the school team use the indicators as a starting point for developing their own shared understanding.

Participants assess by ticking one of four choices offered against each of the indicators:

- Needs major work

- Needs some work

- OK for now

- Doing well

There is also space for any additional relevant facts particular to the school or for comments. The results are collated and those indicators that are most in need of work are identified.

Step 4. Prioritisation of topics that reflect school needs

The results of this self-assessment form the basis of the next step which is to prioritise the indicators in need of work, taking into account such factors as importance, cost, simplicity, time to enact and the number of people affected. Indicators to work on are selected from the prioritised list. The guide suggests that the team takes into account what can reasonably be accomplished within one school year.

Step 5. Communication with Board of Trustees and school community

At this time it may be necessary to inform the school staff, Board of Trustees and any other concerned parties, of the team's self assessment ratings and ranked priorities. This is not only an act of courtesy, but will alert those groups to intended action that may affect them or may involve their consent and participation. 
Step 6. Creation of action plans to address schools prioritised needs

The Guide suggests at this point that the team should look to itself and other local schools to check if there are any existing options that could be adopted or adapted. The website for the Center on Disability and Community Inclusion at University of Vermont (www.uvm.edu/ cdci/parasupport/) also has suggestions for each of the priorities.

If no existing solutions are available, the team then needs to create its own - an opportunity to custom fit a plan that will be particular to each school. The Guide suggests the use of problem solving strategies and gives an example of a suitable one (Parnes, 1997). This problem solving process emphasises the use of both divergent thinking (being open to new ideas) and convergent thinking (focusing in and making judgements).

Worksheets are provided to assist the team with the problem solving process (Appendix

B). Criteria are given and scoring systems suggested to assist the team in identifying the most promising ideas generated by brainstorming. The Guide cautions that the scoring system should not be used as a formula to make decisions but rather as a method to guide the evaluation and promote discussion. Once the ideas have been selected, then plans of action can be developed, specifying the priority idea, the proposed impact, what actions will be taken, who will be involved, a timeline and a plan for evaluating the impact (Appendix C).

\section{Step 7. Identification of relevant resources}

The school team identifies any local, regional, nationwide or other resources that might assist in achieving the team's plans.

\section{Step 8. Implementation of action plans}

This step involves the team keeping a record of the process of the implementation of the plans, including any adjustments that may need to be made. 
Step 9. Evaluation of impact of plans

The Guide offers a list of suggestions to aid the team in planning the evaluation.

1. What information will need to be collected to determine whether the plan of action has had its intended impact?

2. How will it be collected and from whom?

3. When will the information be collected?

4. Who will organise, analyse, and interpret the information?

5. Summarise and review with the team.

6. Make decisions, based on the information, about what needs to happen next. (It also noted that any relevant reports or extra information could be used in the evaluation).

Step 10. Communication of impact to school community

A brief written summary of the impact of the actions taken, on teacher aides, students, teachers, special educators and parents is to be shared with school community and any other appropriate groups.

The team can revisit the self-assessment and identified priorities and select new challenges.

\section{The NZ Guide}

With the permission and assistance of Dr Michael Giangreco, The Guide was adapted to make it user-friendly in a New Zealand school. The changes were minor and entirely semantic. This adapted version 'A Guide to Schoolwide Planning for Teacher Aide Supports' (New Zealand Version) was used throughout this study and will be referred to as “The NZ Guide”.

This study replicated the work of Giangreco et al (2003) in a New Zealand setting. It chronicled the use and evaluated the effectiveness of The NZ Guide in a New Zealand primary school. It focused on: 
1. the effectiveness of the guide in taking the Teacher Aide Support Team (TAST) through the process.

2. the impact of the guide on the school, both direct and indirect.

It used evaluation as a method of educational enquiry. The evaluation was both formative and summative in nature, formative inasmuch as some of the data were collected in order to improve the process itself and summative because data were gathered on the impact of the process on school personnel and student outcomes.

\section{Research questions}

What are the issues in the implementation of 'A Guide to Schoolwide Planning for Teacher Aide Supports' (New Zealand Version) in a school that has students with special education needs in the regular setting?

Specifically:

1. How does the school evaluate itself on 28 indicators of teacher aide support?

2. What are the school's self identified teacher aide priorities?

3. What actions does the school take to address its teacher aide priorities?

4. How do team members rate the teacher aide planning process on whether it does what it purports to do (i.e. help schools select appropriate priorities, develop plans to address identified priorities) and consumer oriented variables (i.e. importance, ease of use)?

5. What are participants' perspectives on the strengths, weaknesses, and suggestions for improving the teacher aide planning process?

6. What impact does the teacher aide planning process have on personnel and students? 


\section{CHAPTER FOUR}

\section{Methodology}

This study examined how The NZ Guide was implemented in a New Zealand primary school. This chapter outlines data collection methods, the sources of data, the research questions and the 10 procedural steps that were followed. The nature of the study was both formative and summative. The chapter documents how the Teacher Aide Support Team (TAST), a voluntary group of representative adult school personnel, proceeded at each step depending on data gathered and decisions made on the previous step. Therefore it was necessary to document the outcomes of each procedural step. Whilst these outcomes could be regarded as results, it was important to indicate their presence within this chapter on methodology. These procedural results will be discussed in the results chapter in more detail.

\section{Data Collection Methods and Sources}

Data were collected from five different sources - The NZ Guide itself, questionnaires, interviews, permanent products and meeting notes and tapes.

\section{The NZ Guide}

The NZ Guide served a dual purpose. It was in the form of a workbook that guided the team, step by step, through the process. It was also used to record the process and therefore was a source of data.

The NZ Guide contained a self-assessment survey (Appendix A) listing 28 indicators of teacher aide support under six headings of acknowledgement, orientation and training, hiring and assigning, interactions, roles and responsibilities and, supervision and evaluation. The school community rated the school on the 28 indicators of teacher aide support using four criteria: (a) needs major work, (b) needs some work, (c) OK for now and, (d) doing well.

The NZ Guide also contained a brainstorming worksheet (Appendix B) to assist the TAST to decide on the best actions for the identified priorities. The worksheet suggested the following six criteria for the brainstormed action ideas: (a) simplicity (b) 
'do-ability', (c) cost, (d) time frame, (e) equity/staff affected and, (f) impact on students. It also provided a record of the process of action planning.

An outline for the plans of action (Appendix C) stating what was to be done, by whom, with a time line and a guide to evaluating the actions taken, was also provided.

Individual team member questionnaire

This questionnaire (Appendix D) was administered to the TAST at the end of the planning process (Step 7). It gave information on the participants' perspectives on

- Whether the planning process did what it purported to do.

- Variables such as importance, ease of use etc.

- The strengths and weaknesses of the planning process and suggestions for improvement.

Team members were asked to respond to seven evaluative statements using a Likertstyle scale where one was "strongly disagree” and four was "strongly agree”. Three additional questions were open ended, requiring the team members to give brief written responses on the strengths and weaknesses of the process and to offer suggestions for improvement.

\section{Teacher aide questionnaire}

The teacher aide questionnaire (Appendix E) was given to the teacher aides at the conclusion of the study in order to ascertain the effectiveness of the plans.

\section{Semi-structured interviews with TAST members}

These interviews (Appendix F) were conducted at the agreed conclusion of the study. The semi-structured interviews were taped, transcribed and examined for themes and areas of agreement and disagreement. The questions were structured to tap into the views of the participants on the impact of the process on students and school personnel. The participants in the semi-structured interview were given the questions beforehand, so that they had the opportunity to make notes before the actual interview.

\section{Permanent products}

These documents were evidence of some of the outcomes of the process and consist of: 
- The guidelines for teachers to use with teacher aides at the beginning of the school year (Appendix G).

- The teacher aide orientation checklist for school staff to work through (Appendix H).

- The Learning Support Plan - devised as a communication tool for teachers and teacher aides (Appendix I).

Meeting/observation notes and tapes

Meeting notes and audiotapes of all TAST meetings were kept for triangulation purposes.

\section{Data Analysis}

The self-assessment survey was analysed by counting the number of ticks in each of the four categories: “needs major work”, “needs some work”, “ok for now” and “doing well”, for each of the 28 indicators across all the constituencies. The raw scores were then converted into percentages of the total number of participants (32 participants). A percentage was also given for indicators that were not rated (see Table 5.1) in results chapter).

The individual TAST questionnaire was administered to the team which consisted of five members (researcher and parent representative not counted). As the number of participants for this questionnaire was small, it was not feasible to gather statistical data, so raw scores were noted, as were the responses to the open ended questions. The teacher aide questionnaire was likewise administered to a small group of teacher aides and so again, raw scores only were noted.

The semi structured interviews were administered to the five team members who wrote their answers prior to the interviews, which were in turn taped and transcribed. The written answers and transcriptions were examined for comments on the types and frequency of impact of the process. The permanent products, meeting notes and tapes served as data for triangulation. 


\section{Research Questions}

The overall research question was: 'What are the issues in the implementation of 'A Guide to Schoolwide Planning for Teacher Aide Supports' (New Zealand Version) in a school that has students with special education needs in the regular setting?' Table 4.1 outlines the specific research questions, the relevant sources of data and the personnel involved.

Table 4.1: Sources of data and personnel involvement for each research question.

\begin{tabular}{|c|c|c|}
\hline Research question & Source of data & Personnel \\
\hline $\begin{array}{l}\text { How does the school } \\
\text { evaluate itself on } 28 \\
\text { indicators of teacher } \\
\text { aide support? }\end{array}$ & The self-assessment survey & All school personnel \\
\hline $\begin{array}{l}\text { What are the school's } \\
\text { self identified teacher } \\
\text { aide priorities? }\end{array}$ & $\begin{array}{l}\text { The planning guide } \\
\text { workbook records } \\
\text { Meeting notes }\end{array}$ & $\begin{array}{l}\text { Teacher Aide Support } \\
\text { Team (TAST) } \\
\text { Participant observer }\end{array}$ \\
\hline $\begin{array}{l}\text { What actions does the } \\
\text { school take to address } \\
\text { its teacher aide } \\
\text { priorities? }\end{array}$ & $\begin{array}{l}\text { The planning guide } \\
\text { workbook records } \\
\text { Meeting notes } \\
\text { Permanent products }\end{array}$ & $\begin{array}{l}\text { TAST } \\
\text { Participant observer } \\
\text { TAST }\end{array}$ \\
\hline $\begin{array}{l}\text { How do team members } \\
\text { rate the teacher aide } \\
\text { planning process on } \\
\text { whether it does what it } \\
\text { purports to do? }\end{array}$ & $\begin{array}{l}\text { Individual team member's } \\
\text { questionnaire }\end{array}$ & TAST \\
\hline $\begin{array}{l}\text { What are participants' } \\
\text { perspectives on the } \\
\text { strengths, weaknesses, } \\
\text { and suggestions for } \\
\text { improving the teacher } \\
\text { aide planning process? }\end{array}$ & $\begin{array}{l}\text { Individual team member } \\
\text { questionnaire }\end{array}$ & TAST \\
\hline $\begin{array}{l}\text { What impact does the } \\
\text { teacher aide planning } \\
\text { process have on } \\
\text { personnel and students? }\end{array}$ & $\begin{array}{l}\text { Semi structured interviews } \\
\text { Teacher aide questionnaire } \\
\text { Permanent products }\end{array}$ & $\begin{array}{l}\text { TAST } \\
\text { All teacher aides } \\
\text { TAST }\end{array}$ \\
\hline
\end{tabular}




\section{Procedures}

The procedure for the project was set out in The NZ Guide following the 10 steps below:

Step

1. Communication with Board of Trustees.

2. Selection of appropriate TAST members.

3. Self-assessment of school status on teacher aide topics.

4. Prioritisation of topics that reflect school needs.

5. Communication with Board of Trustees and school community.

6. Creation of action plans to address schools prioritized needs.

7. Identification of relevant resources.

8. Implementation of action plans.

9. Evaluation of impact of plans.

10. Communication of impact to school community.

Step 1. Communication with Board of Trustees

The participating school was recruited through personal contact and was selected on the basis of the following criteria:

a) placement of students with special education needs in regular classroom settings,

b) employment of teacher aides to provide educational supports, and

c) a voluntary commitment to the research.

It is a full primary school situated in a coastal suburb with a mixture of rental and privately owned properties. The school is rated as a decile five school (on a scale of one to ten, decile one is a school situated in a low socio-economic area and decile ten in a high socio- economic area). The school has 502 students across 21 classes. The school's ethnic composition is: Pakeha $83 \%$, Maori 13\%, Pacific Nations $2 \%$, others $2 \%$. The gender composition is $50 \%$ girls and $50 \%$ boys.

Communication with the Board of Trustees was done through the staff representative on the Board and the Special Education Needs Coordinator (SENCO). An overview of the project was presented and approval given. A donation from a local Rotary Club was given to the school to offset any administration costs it might incur. 
Step2. Selection of Appropriate TAST Members

The participants in the study were a team of six volunteers, who represented the adult school community. i.e. Board of Trustees, management, teachers, teacher aides and parents. As the researcher, I took the role of coordinator and participant observer.

Staff.

After gaining the school's agreement to participate, I conducted a staff meeting to present an overview of the process. An information sheet was distributed and staff had the opportunity to ask questions and request more detail. A copy of The NZ Guide was left at the school for staff to read in order to help them to decide whether or not they would like to be participants in the team needed for the research. The SENCO also approached key personnel. Four staff members volunteered.

\section{Teacher Aides.}

A meeting with the teacher aides was organised by the SENCO. They had not attended the staff meeting as it was outside of their hours of employment. This meeting offered the same information, with question and answer opportunities, as had been given to the staff. At this meeting the teacher aides unanimously endorsed one teacher aide who had volunteered to be the teacher aide representative on the team.

\section{Parents.}

Parents were approached by the SENCO, who had the best knowledge of parents with children receiving teacher aide support in the school. One parent volunteered to think about it. I went to that parent's home and had a discussion regarding her involvement. The parent received the same information that had been given to the previous two groups. She then volunteered to be a part of the team.

From these meetings a voluntary team was formed and named the Teacher Aide Support Team (TAST). The team consisted of: 
- One senior management representative (Deputy Principal)

- One middle management representative (SENCO)

- Two teachers who also had responsibility for students on the Ongoing and Reviewable Resourcing Scheme, (ORRS). One of these teachers was also the staff representative on the school's Board of Trustees.

- One teacher aide who worked with students with special education needs.

- One parent of students with special education needs.

- One RTLB (Resource Teacher Learning and Behaviour) - the researcher, coordinator, and participant observer.

TAST members were given participant information sheets (Appendix J) and consent forms (Appendix K) to sign.

\section{Step 3. Self-assessment of School Status on Teacher Aide Indicators}

This step required the team to assess the school's status on its teacher aide supports of students with special education needs using the 28 indicators in the self-assessment survey (Appendix A). The indicators were rated on one of the following: needs major work, needs some work, OK for now, doing well.

At the first TAST meeting, the team decided that all school personnel should be involved in the self-assessment of the 28 indicators of teacher aide support. (This differed from the US study as only the team members took part in the self-assessment process). To this end, all adult school personnel were given a copy of the selfassessment form with a time line for return - this was co-ordinated by the deputy principal. It was pointed out to the school personnel that if any individuals felt unsure or unqualified to assess on any of the indicators, because of lack of knowledge or experience, then it was acceptable for them to leave that indicator blank or to comment if they so wished.

The team decided that only a small cross section of parents would be canvassed, as it was considered that to involve all parents would be beyond the resources of this study. A letter of explanation accompanied the self-assessment form and parents also had access to the researcher and the parent representative. 
The constituencies that participated in the survey were:

- Management (senior and middle)

- Teaching staff (both regular and special education)

- Teacher aides

- Support staff (administration, caretaker, librarian)

- Parents

The six most highly rated overall as needing “major work” or "some work” were:

1. Relief teacher aides should be recruited and trained to ensure that a student's access to education and participation in his/her educational programme is not unduly disrupted when the regular teacher aide is unavailable due to illness, injury, personal leave, or professional development. (68\%)

2. Times and mechanisms should be established to allow opportunities for teacher aides to be oriented to teacher's plans, report on student progress, ask questions, and offer their perspectives. (53.5\%)

3. In most circumstances it is advisable to assign teacher aides to classrooms or instructional programmes rather than an individual student. In the rare cases when a teacher aide is needed for an individual student, efforts should be made to ensure that teacher aides provide supportive, rather than primary or exclusive, services. (47.5\%)

4. When teacher aide support is determined to be necessary for a student, a written plan should explicitly clarify the nature and extent of the support and explain how it is referenced to the student's educational programme (e.g., IEP goals, National Curriculum). (37.5\%)

5. Schools should develop ways to evaluate the impact of teacher aide services on individual students, classrooms and staff. (37.5\%)

6. Teacher aides should receive orientation (e.g., information about the student, classroom and school) and entry level training prior to working directly with 
students (e.g., teamwork, inclusive education, roles and responsibilities of team members, principles of learning). (34\%)

\section{Step 4. Prioritisation of Indicators that Reflect School Needs}

The results of the school's self-assessment were presented to the team. (see Table 5.1 in results chapter) They elected to take some time to look over the results, especially at the individual constituency's percentages to determine the priorities on which to focus. It was decided that if any one constituency had rated particular indicators highly on "needs major work" and "needs some work", which differed from the overall results, then these indicators should also be considered.

The team then identified priorities using, (a) the results of the self-assessment and (b), the criteria of importance, cost, simplicity, time to enact and the number of people affected, as recommended in The NZ Guide.

As a result of this, the six most highly rated indicators in the overall combined "needs major work" and "needs some work” categories were discussed and two priorities chosen. These were: (1) times and mechanisms for teachers and teacher aides to meet and, (2) orientation and training.

\section{Step 5. Communication with Board of Trustees and School Community}

The team then compiled a letter to the principal, staff and Board of Trustees to inform them of the progress to date, in particular to inform them of the priorities on which the TAST intended to work.

\section{Step 6. Creation of Action Plans to Address Schools Prioritised Needs}

The remaining six meetings in the school year were taken up with the processes of: (a) brainstorming ideas to address the priorities, (b) working through the problem solving process suggested in The NZ Guide and, (c) developing plans of action which specified the priority ideas or solutions, the proposed impact, actions to be taken and methods of evaluating the impact. 
Priority one.

Times and mechanisms should be established to allow opportunities for teacher aides to be oriented to teacher's plans, report on student progress, ask questions, and offer their perspectives.

Following the creative problem solving strategies (Parnes, 1997), shown in The NZ Guide (Appendix B), this was restated as:

In what ways might we establish times and mechanisms to allow opportunities for teacher aides to be oriented to teachers' plans, report on student progress, ask questions and offer their perspectives?

Ideas were generated and rated on a scale from 1-3 (Table 4.2). 
Table 4.2: Brainstormed ideas for Priority One with ratings based on a set of determined criteria.

\begin{tabular}{|c|c|c|c|c|c|c|c|c|}
\hline & Idea & Simplicity & $\begin{array}{c}\text { do- } \\
\text { ability' }\end{array}$ & cost & $\begin{array}{l}\text { time } \\
\text { frame }\end{array}$ & equity & $\begin{array}{c}\text { impact } \\
\text { on } \\
\text { students }\end{array}$ & Total \\
\hline 1 & $\begin{array}{l}\text { Make time on } \\
\text { "Teacher Only" day }\end{array}$ & 3 & 3 & 3 & 3 & 3 & 3 & 18 \\
\hline 2 & $\begin{array}{l}\text { SENCO release for } \\
\text { teachers in Week } 3 \\
\text { Term } 1\end{array}$ & 3 & 3 & 3 & 3 & 3 & 3 & 18 \\
\hline 3 & $\begin{array}{l}\text { Teacher/Teacher } \\
\text { Aide notebook/ } \\
\text { timetable or } \\
\text { Learning Support } \\
\text { Plan }\end{array}$ & 3 & 3 & 3 & 2 & 2 & 3 & 16 \\
\hline 4 & $\begin{array}{l}\text { Teacher takes } 2 \\
\text { classes to assemblies }\end{array}$ & 2 & 3 & 3 & 2 & 3 & 3 & 16 \\
\hline 5 & $\begin{array}{l}\text { "In Class" meeting } \\
\text { with 2nd teacher } \\
\text { aide supervising } \\
\text { class activities }\end{array}$ & 3 & 3 & 3 & 2 & 1 & 1 & 13 \\
\hline 6 & $\begin{array}{l}\text { Meeting at end of } \\
\text { previous year }\end{array}$ & 1 & 2 & 3 & 1 & 3 & 3 & 2 \\
\hline 7 & $\begin{array}{l}\text { Use of students' } \\
\text { 'time' }\end{array}$ & 1 & 2 & 3 & 2 & 1 & 2 & 11 \\
\hline 8 & $\begin{array}{l}\text { Accumulate time by } \\
\text { starting late or } \\
\text { finishing early }\end{array}$ & 1 & 2 & 3 & 1 & 1 & 1 & 9 \\
\hline 9 & $\begin{array}{l}\text { Teachers without } \\
\text { teacher aides taking } \\
\text { morning tea/lunch } \\
\text { duties }\end{array}$ & 1 & 1 & 3 & 1 & 1 & 1 & 8 \\
\hline 10 & Doubling up classes & 1 & 1 & 3 & 1 & 1 & 1 & 8 \\
\hline 11 & $\begin{array}{l}\text { Paid meetings for } \\
\text { teacher aides }\end{array}$ & 1 & 1 & 1 & 1 & 1 & 1 & 6 \\
\hline
\end{tabular}

Scale: 1 - not such a good idea; 2 - possible; 3 - great idea 
The two ideas that rated the maximum points were then developed into Plan of Action (1) (Appendix L), and Plan of Action (2) (Appendix M). “Teacher Only” days are days set aside, at a school's discretion, during the school year for professional development for staff. The team considered that there should be guidelines for teachers to use on the “Teacher Only” day in their information sharing sessions with the teacher aides, so that there would be some uniformity to the sessions. These guidelines were devised by the TAST (Appendix G). It was to be a prerequisite that both parties had read the teacher aide's job description, any Individual Education Plans (IEPs) and any relevant synopses of individual student's needs.

Quotes from meeting:

Re: “Teacher Only” day:

"It would be invaluable for teachers to meet up with new teacher aides and to give them insights into the child."

"Sometimes the teacher aide knows the child really well and it would be a valuable time for them to impart their knowledge."

"It would be nice if the teacher aides could be included in the lunch."

"It's much easier if you can cover stuff ahead of time, forewarn and give useful tips."

"It would be really useful for the teacher aides to know what was expected of them in the first couple of weeks of Term 1 when we (teachers) are still getting to grips with our classes.”

"We could organise it so that the teacher aides were either paid or had time in lieu for attending the Teacher Only day."

Re: Week 3 release:

"I like the idea of having an agenda - both teacher and teacher aide can write on it."

"You can put anything on it that you want to discuss."

"You will know more about the job by Week 3."

"Things crop up that you want to talk about - it's a good idea to write them down."

"It will be good to have time to talk." 
The teacher aide support team then put together a questionnaire to evaluate the two action plans that they had designed, (Appendix E).

Priority two.

Teacher aides should receive orientation (e.g., information about the student, classroom and school) and entry-level training prior to working directly with students (e.g., teamwork, inclusive education, roles and responsibilities of team members, principles of learning).

The question posed by restating this priority was:

In what ways might we provide orientation for teacher aides (e.g., information about the student, classroom and school) and entry-level training prior to working directly with students (e.g., teamwork, inclusive education, roles and responsibilities of team members, principles of learning)?

Ideas were generated and rated on a scale from 1-3 (Table 4.3). 
Table 4.3: Brainstormed ideas for Priority Two with ratings based on a set of determined criteria.

\begin{tabular}{|l|l|l|l|l|l|l|}
\hline Idea & $\begin{array}{l}\text { Simpli- } \\
\text { city }\end{array}$ & $\begin{array}{c}\text { do- } \\
\text { ability' }\end{array}$ & cost & $\begin{array}{c}\text { time } \\
\text { frame }\end{array}$ & Equity & $\begin{array}{c}\text { impact } \\
\text { on } \\
\text { students }\end{array}$
\end{tabular}

\begin{tabular}{|c|c|c|c|c|c|c|c|c|}
\hline 1 & $\begin{array}{l}\text { Update orientation } \\
\text { checklist }\end{array}$ & 3 & 3 & 3 & 3 & 3 & 3 & 18 \\
\hline 2 & $\begin{array}{l}\text { Copy to all teacher } \\
\text { aides and included } \\
\text { in staff manual }\end{array}$ & 3 & 3 & 3 & 3 & 3 & 3 & 18 \\
\hline 3 & $\begin{array}{l}\text { Deputy Principal to } \\
\text { ensure training } \\
\text { opportunities are } \\
\text { included in staff } \\
\text { manual }\end{array}$ & 3 & 3 & 3 & 3 & 3 & 3 & 18 \\
\hline 4 & $\begin{array}{l}\text { Update current } \\
\text { teacher aides on } \\
\text { contents of staff } \\
\text { manual }\end{array}$ & 2 & 3 & 3 & 2 & 3 & 3 & 16 \\
\hline
\end{tabular}

$\begin{array}{ll}5 & \text { Revisit existing } \\ \text { school manuals. e.g. } \\ \text { Learning support, } \\ \text { behaviour } \\ \text { management }\end{array}$
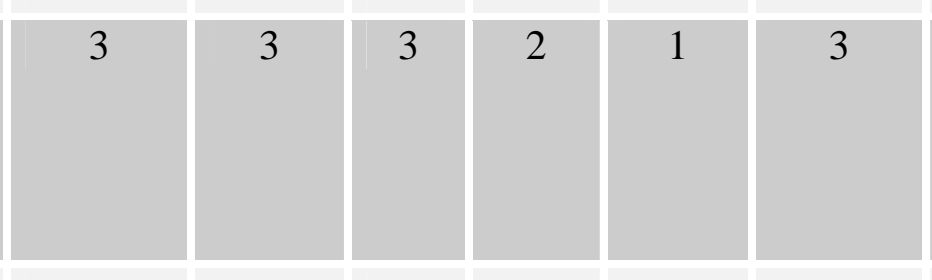
6 Use of outside agencies such as RTLB, GSE, SLT, Deaf Advisor
7 Buddy new teacher aides with existing teacher aide
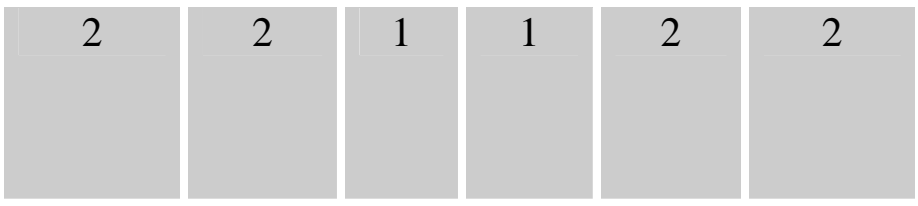

Abbreviations: RTLB -Resource Teacher Learning and Behaviour

\section{GSE- Group Special Education}

SLT - Speech Language Therapist

(It was commented on that the "Teacher Only" day meeting would also serve as a good orientation activity - especially for new teacher aides). 
All these ideas were rated closely, but the team decided to target the first three ideas updating current checklist, revisiting existing manuals and advertising training opportunities. A Plan of Action (3) (Appendix N) was written for the preferred ideas.

Quotes from the meeting:

Re: orientation checklist (Appendix H) and manuals:

"It is a priority for new people and quite frankly even with all my experience - there are some things that I did not know - it was a learning curve for me."

"It takes a long time to work through it all-it's an ongoing process and people need to be reminded."

“We need to update current teacher aides."

"We need a copy of the checklist every year."

"It's a long term, on-going process - people forget."

"It needs to be included in the staff manual."

"It needs to be reviewed regularly."

Re: training:

"SENCO trains TAs as and when is needed - case by case."

"Outside agencies such as RTLB, SLT, GSE and other itinerant teachers do professional development with TAs.”

“I will advertise relevant courses at morning tea.” (DP)

"TA observes the child and other TAs."

"Action plans 1 and 2 will deal with some of these issues."

Further questions were added to the teacher aide questionnaire (Appendix E) to evaluate the effectiveness of this plan.

Step 7. Identification of Relevant Resources

The team looked at:

a) orientation manuals from other primary schools in the district, but decided that they preferred doing the orientation in a way that best suited their own school and, 
b) learning support plans devised by other schools, but again, preferred the systems that they were already using.

Step 8. Implementation of Action Plans

Plans of Action (1) \& (2) were adapted (see results section) and implemented at the start of the school year. Plan of Action (3) was implemented at the same time.

\section{Step 9. Evaluation of Impact of Plans}

The teacher aide questionnaire (Appendix E) was distributed to all teacher aides to evaluate the Plans of Action (1), (2) and (3) at the agreed conclusion of the research. The questionnaire completed by the teacher aides and the semi structured interviews with the TAST (Appendix F) give a picture of the school's evaluation of the impact of the plans of action on the school community. These are covered more fully in the results section of the thesis.

Step 10. Communication of Impact to School Community

A written report on the research was given to the school staff and Board of Trustees and made available to the parents and community. 


\section{CHAPTER FIVE}

\section{Results}

The results of this study are reported under the six research questions.

\section{How does the school rate itself on 28 indicators of teacher aide support?}

Source: Whole school self-assessment survey.

The percentage of returns were as follows:

Management $2 / 3=66.6 \%$

Teaching staff $17 / 22=77.2 \%$

Teacher aides $8 / 8=100 \%$

Support staff $3 / 3=100 \%$

Parents $2 / 4=50 \%$

For the sake of clarity, only the six highest rating (i.e. 6 of 28) in the combined "needs major work" and "needs some work" categories are reported in depth in this section. Table 5.1 shows the percentages for the ratings given by individual constituencies and overall ratings for each of the 28 indicators of effective teacher aide support. Table 5.2 shows overall priority ranking and self assessment ratings based on all 28 indicators of teacher aide support. Table 5.3 shows the results of the six highest indicators in the combined "needs major work" and "needs some work" categories and Table 5.4 the combined "ok for now" and "doing well” categories. The results for the teacher aide constituency are shown in Tables 5.5 and 5.6. 
Table 5.1 Self assessment results of teacher aide topics: Percentages for each constituency and overall percentages.

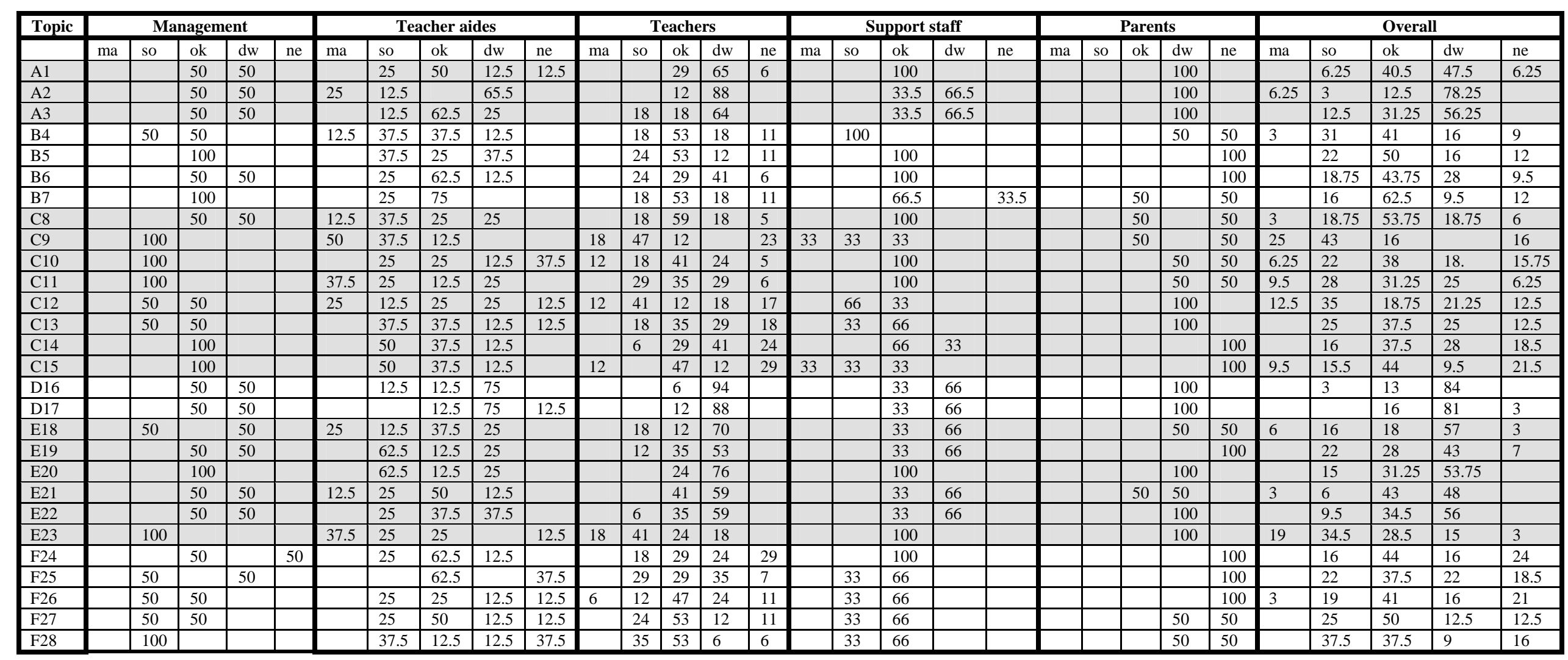

ma = needs major work

so $=$ needs some work

ok $=$ ok for now

dw $=$ doing well

ne $=$ not entered 
Table 5.2. Priority ranking and self-assessment rating based on indicators of teacher aide support.

\begin{tabular}{|c|c|c|c|c|c|c|}
\hline Priority Rank & $\begin{array}{l}\text { Abbreviated indicators (item number from 'A guide to schoolwide planning for } \\
\text { teacher-aide supports') }\end{array}$ & $\begin{array}{c}\%(\mathrm{n}) \\
\text { Needs Major } \\
\text { Work }\end{array}$ & $\begin{array}{c}\%(\mathrm{n}) \\
\text { Needs Some } \\
\text { Work }\end{array}$ & $\begin{array}{c}\%(\mathrm{n}) \\
\text { OK for now }\end{array}$ & $\begin{array}{c}\%(\mathrm{n}) \\
\text { Doing Well }\end{array}$ & $\begin{array}{c}\%(\mathrm{n}) \\
\text { Not Entered }\end{array}$ \\
\hline 1 & Relief teacher aides recruited and trained (9) & $25.00(8)$ & $43.00(14)$ & $16.00(5)$ & $0.00(0)$ & $16.00(5)$ \\
\hline 2 & Times and mechanisms to work with teachers (23) & $19.00(6)$ & $34.50(11)$ & $28.50(9)$ & $15.00(5)$ & $3.00(1)$ \\
\hline 3 & Teacher aides assigned to classroom rather than 1:1(12) & $12.50(4)$ & $35.00(11)$ & $18.75(6)$ & $21.25(7)$ & $12.50(4)$ \\
\hline 4 & Written plan clarifying nature/extent of support(11) & $9.50(3)$ & $28.00(9)$ & $31.25(10)$ & $25.00(8)$ & $6.25(2)$ \\
\hline 4 & Evaluate impact of teacher aide services (28) & $0.00(0)$ & $37.50(12)$ & $37.50(12)$ & $9.50(3)$ & $16.00(5)$ \\
\hline 6 & Orientation and entry-level training (4) & $3.00(1)$ & $31.00(10)$ & $41.00(13)$ & $16.00(5)$ & $9.00(3)$ \\
\hline 7 & Determining if teacher aide support is needed (10) & $6.25(2)$ & $22.00(7)$ & $38.00(12)$ & $18.75(6)$ & $15.00(5)$ \\
\hline 8 & Plan to evaluate fading of teacher aide support (27) & $0.00(0)$ & $25.00(8)$ & $50.00(16)$ & $12.50(4)$ & $12.50(4)$ \\
\hline 8 & Team input on assignments and reassignments (13) & $0.00(0)$ & $25.00(8)$ & $37.50(12)$ & $25.00(8)$ & $12.50(4)$ \\
\hline 8 & Compensated for education, experience, skills (15) & $9.50(3)$ & $15.5(5)$ & $44.00(14)$ & $9.50(3)$ & $21.50(7)$ \\
\hline 11 & Practices to recruit, hire and retain teacher aides (8) & $3.00(1)$ & $18.75(6)$ & $53.50(17)$ & $18.75(6)$ & $6.00(2)$ \\
\hline 11 & On-the- job training to match responsibilities (5) & $0.00(0)$ & $22.00(7)$ & $50.00(16)$ & $16.00(5)$ & $12.00(4)$ \\
\hline 11 & Teacher aides part of school improvement plan (26) & $3.00(1)$ & $19.00(6)$ & $41.00(13)$ & $16.00(5)$ & $21.00(7)$ \\
\hline 11 & Teacher aides receive ongoing supervision (25) & $0.00(0)$ & $22.00(7)$ & $37.50(12)$ & $22.00(7)$ & $18.50(6)$ \\
\hline 11 & Work is directed by teachers \& special educators (18) & $6.00(2)$ & $16.00(5)$ & $18.00(6)$ & $57.00(18)$ & $3.00(1)$ \\
\hline 11 & Professional staff have ultimate responsibility (19) & $0.00(0)$ & $22.00(7)$ & $28.00(9)$ & $43.00(14)$ & $7.00(2)$ \\
\hline 17 & Access to ongoing learning opportunities (6) & $0.00(0)$ & $18.75(6)$ & $43.75(14)$ & $28.00(9)$ & $9.50(3)$ \\
\hline 17 & Teacher aide training is credited towards qualifications (7) & $0.00(0)$ & $16.00(5)$ & $62.50(20)$ & $9.50(3)$ & $12.00(4)$ \\
\hline 17 & Supervisors of teacher aides trained to supervise (24) & $0.00(0)$ & $16.00(5)$ & $44.00(14)$ & $16.00(5)$ & $24.00(8)$ \\
\hline 17 & Accurate job description (14) & $0.00(0)$ & $16.00(5)$ & $37.50(12)$ & $28.00(9)$ & $18.50(6)$ \\
\hline 17 & Informed of educational needs (e.g., IEP goals) (20) & $0.00(0)$ & $16.00(5)$ & $31.00(10)$ & $53.00(17)$ & $0.00(0)$ \\
\hline 17 & Teacher aides are valued, appreciated, recognised (3) & $0.00(0)$ & $12.50(4)$ & $31.25(10)$ & $56.25(18)$ & $0.00(0)$ \\
\hline 23 & Teacher aides carry out a wide variety of supports (22) & $0.00(0)$ & $9.50(3)$ & $34.50(11)$ & $56.00(18)$ & $0.00(0)$ \\
\hline 23 & Teacher aides provide important services (2) & $6.25(2)$ & $3.00(1)$ & $12.50(4)$ & $78.25(25)$ & $0.00(0)$ \\
\hline 23 & Teacher aides contribute, not solely responsible (21) & $3.00(1)$ & $6.00(2)$ & $43.00(14)$ & $48.00(15)$ & $0.00(0)$ \\
\hline 23 & Teacher aides should be team members (1) & $0.00(0)$ & $6.00(2)$ & $41.00(13)$ & $47.00(15)$ & $6.00(2)$ \\
\hline 27 & Demonstrate constructive interpersonal skills (16) & $0.00(0)$ & $3.00(1)$ & $12.50(4)$ & $84.50(27)$ & $0.00(0)$ \\
\hline 28 & Teacher aides promote inter - and independence (17) & $0.00(0)$ & $0.00(0)$ & $16.00(5)$ & $81.00(26)$ & $3.00(1)$ \\
\hline
\end{tabular}


As can be seen from the results, there was a high level of satisfaction overall within the school with regard to teacher aide supports. With the exception of the issues of relief teacher aides and times and mechanisms for teachers and teacher aides to meet, the overall percentages for the combined "needs major work" and "needs some work" categories did not rise above 50\%. Whereas the percentages for the combined "ok for now” and “doing well” categories did not fall below 50\% for 24 of the 28 indicators.

Table 5.3: The six indicators of teacher aide support with the highest overall combined "needs major work" and "needs some work" percentages.

\begin{tabular}{|l|c|}
\hline Indicators & $\%$ \\
\hline Relief teacher aides recruited and trained & 68 \\
\hline Times and mechanisms to work with teachers & 53.5 \\
\hline Teacher aides assigned to classrooms rather than 1:1 & 47.5 \\
\hline Written plan clarifying nature/extent of work & 37.5 \\
\hline Evaluate impact of teacher aide services & 37.5 \\
\hline Orientation and entry level training & 34 \\
\hline
\end{tabular}

Table 5.4: The six indicators of teacher aide support with the highest overall combined “ok for now" and “doing well” percentages.

\begin{tabular}{|l|c|}
\hline Indicators & $\%$ \\
\hline Teacher aides demonstrate constructive interpersonal skills & 97 \\
\hline Teacher aides promote inter- and independence & 97 \\
\hline Teacher aides contribute, not solely responsible & 92 \\
\hline Teacher aides provide important services & 90.75 \\
\hline Teacher aides carry out a variety of supports & 90.5 \\
\hline Teacher aides should be team members & 88 \\
\hline
\end{tabular}


Table 5.5: Teacher aides' ratings - highest combined “needs major work" and "needs some work" percentages.

\begin{tabular}{|l|c|}
\hline Indicators & $\%$ \\
\hline Relief teacher aides recruited and trained & 87.5 \\
\hline Written plan clarifying nature/extent of support & 62.5 \\
\hline Professional staff have ultimate responsibility & 62.5 \\
\hline Informed of educational needs & 62.5 \\
\hline Times and mechanisms to work with teachers & 62.5 \\
\hline Orientation and entry-level training & 50 \\
\hline Practices to recruit hire and retain teacher aides & 50 \\
\hline Accurate job description & 50 \\
\hline Compensated for education, experience, skills & 50 \\
\hline
\end{tabular}

Table 5.6: Teacher aides' ratings - highest combined "ok for now" and "doing well” percentages.

\begin{tabular}{|l|c|}
\hline Indicators & $\%$ \\
\hline Teacher aides are valued, appreciated, recognised & 87.5 \\
\hline Demonstrate constructive interpersonal skills & 87.5 \\
\hline Teacher aides promote inter - and independence & 87.5 \\
\hline Access to ongoing learning opportunities & 75 \\
\hline Teacher aides carry out a wide variety of supports & 75 \\
\hline Supervisors of teachers aides trained to supervise & 75 \\
\hline Teacher aides provide important services & 75 \\
\hline
\end{tabular}

In comparison to the overall ratings, the teacher aide constituency results showed that 9 of the 28 indicators scored over 50\% in the combined "needs major work” and "needs 
some work" categories, and 8 of the 28 indicators scored below 50\% in the "ok for now" and “doing well” categories.

There were four common indicators between overall ratings and those of the teacher aides, in the combined "needs major work" and "needs some work" categories. These were relief teacher aides, written plans, times and mechanisms and, orientation and training. There were also four common indicators in the "ok for now” and "doing well” categories. These were that teacher aides demonstrate constructive interpersonal skills, promote inter- and independence, carry out a variety of supports and provide important services.

The numbers are too small to allow for meaningful statistical analysis of the data.

\section{What are the school's self-identified teacher aide priorities?}

Source: The planning guide workbook, meeting notes and tapes.

The TAST discussed the six highest ranked indicators, with the following decisions being made:

a) Relief teacher aides recruited and trained. Although the team considered that recruiting relief teacher aides would be an ideal solution to teacher aide absences, they decided that it was a topic that they could not influence because of lack of funding.

Comments included:

"There is no allowance or funding available in the New Zealand system"

"It's out of our control"

"There's absolutely nothing we can do"

"We juggle the teacher aides around"

"Teachers just cope”

The team acknowledged that it would be possible to train a pool of relieving teacher aides, but unless schools could guarantee a reasonable amount of work for them, the team considered that people would not come forward to do the training.

b) Times and mechanisms to work with teachers. This was chosen as the first priority on which to work. It was decided at this meeting that the team would start on times and 
mechanisms and see where it would lead, that in fact, by addressing this indicator some of the other topics would also be addressed.

Comments included:

"Lots of things might actually fall into place if we have meetings."

"This would be a good one to start with as it will cover lots of issues."

"It would be good to establish communication right from the start."

c) Teacher aide assigned to classrooms rather than $1: 1$. The team considered that this was already happening in the school except in the rare cases of students who needed very specialised programmes such as the use of Braille. Even though $50 \%$ of the participants indicated that this topic needed “major" or "some” work, the team decided that the participants were stating that they agreed with the indicator rather than considering that it needed to be worked on. They did not interpret any other indicator in this way. Comments included:

"Teacher aides employed under the Special Education Grant often have a programme that they work with rather than an individual student."

"We build a group around the targeted child/children and the teacher aides work with the group."

"Our teacher aides are there for the whole class, mostly, except in very specialised cases where physical assistance is needed."

"In an ideal world, it would be wonderful to have a teacher aide in every classroom.”

d) Written plan clarifying nature/extent of work. The team decided that this would be covered whilst working on times and mechanisms.

e) Evaluate impact of teacher aide services. The team considered this was a topic that could be addressed in the future but did not see it as a priority issue.

Comments included:

“This would be really useful to know.”

"We will have to be very careful about competency issues."

f) Orientation and entry-level training. This was chosen was as the second priority on which to work. The team chose this as it fitted in so well with the first priority and they also considered that the school needed to update its induction procedures. 
Comments included:

“This fits in with 'times and mechanisms' as far as I'm concerned.”

"Our orientation needs looking at anyway."

Times and mechanisms (b), along with orientation and training (f) were chosen as the priorities on which to work.

\section{What actions does the school take to address its teacher aide priorities?}

Source: The planning guide workbook records, meeting notes, tapes and permanent products.

Priority One

Plans of Action One and Two - Meetings between teachers and teacher aides (see Appendices L \& M for details of the plans).

In order to address the priority topics, the TAST decided to request time on the first of their “Teacher Only” days prior to the start of the 2004 school year. The SENCO and DP had negotiated with the principal to have time on the "Teacher Only" day for the teachers and teacher aides to meet and discuss the items on the guidelines which the TAST had developed as a structure for the meeting (Appendix G). This time was to be set immediately prior to lunch so that the teacher aides could then join the teaching staff for lunch. This was considered to be a good way for everyone to get to know each other in a social setting and to make the teacher aides feel valued and appreciated and part of the educational team.

However, these action plans were changed in the last week of the school year 2003. Adjustments to the "Teacher Only" day programme had to be made due to time constraints and it was decided at management level that the teacher aide slot would be left out. The TAST were assured that time would be set aside during the first week of Term 1 2004, for the SENCO to release teachers to meet with their teacher aides to discuss the items set out in the guidelines. There would then be a second round of release time for the second meeting to discuss items on the agenda in weeks 4 and 5 . Items on the agenda, for discussion at the second meeting, were anticipated to have been 
written by the teacher and teacher aide during the first weeks of term one, as per the plans of action (Appendices L \& M).

The SENCO was unable to release teachers in the first week, her reasons being that firstly, her role within the school had changed due to a drop in staffing and she no longer was able to devote as much time to special needs. Secondly, the deputy principal (DP), who was on the TAST, had retired and the new DP was unfamiliar with the plans the TAST had put in place. The SENCO organised meetings during the third and fourth weeks of term one. Further release time was not organised. Therefore the plans of action resulted in only one meeting between the teachers and teacher aides.

Consequently, the results of the teacher aide questionnaire (Table 5.7) showed that even though teacher aides considered that they were able to collaborate, were reasonably informed, clear about their roles and responsibilities, had a good understanding of student needs, were familiar with routines and comfortable with communication, only $40 \%$ were satisfied with the time given for meeting with the teacher.

\section{Priority Two}

Plan of Action Three - Orientation and Training (see Appendix N for details of the plan).

The school already had an "Induction Checklist" - a list of tasks to be undertaken by various personnel (e.g. principal, SENCO, office staff) when new teacher aides were employed. This checklist was updated (Appendix H) by the TAST and implemented by the relevant personnel with the new teacher aides. Copies were distributed to all teacher aides within the school, and a copy included in the Staff Manual. This resulted in some of the responsibility for the orientation resting with the teacher aides. If they considered that they had missed out on any part of the orientation, they could bring this to the attention of the SENCO. One TAST member had taken responsibility for advertising training opportunities and it had proved to be effective. In the teacher aide questionnaire (Table 5.7), the teacher aides stated that they felt more informed about induction procedures and training opportunities. 
4. How do team members rate the teacher aide planning process on whether it did what it purported to do (e.g., help them select appropriate priorities, develop plans to address identified priorities), and consumer variables (e.g., importance, ease of use)?

Source: Individual team members’ questionnaire.

The Likert-style questionnaire (Appendix D) was completed by the TAST members only. It was administered after the plans of action had been written, but before the implementation of the plans. The researcher and the parent representative were not included (the researcher was excluded to remove any bias and the parent representative left the area before the end of the process).

All the five remaining team members "agreed” or "strongly agreed” that the guide had (a) helped them gain insights about teacher aide issues in their school, (b) helped them understand the perspectives of others about teacher aide issues, (c) helped the school select appropriate priorities that required attention, (d) helped the school develop appropriate plans to address self identified priorities, (e) was an important activity for their school, (f) was logical, and (g) was easy to use. Therefore the participants rated the planning process highly on achieving what it set out to do.

\section{What are participants' perspectives on the strengths, weaknesses and suggestions for improving the teacher aide planning process?}

Source: Individual team member's questionnaire.

The two major perspectives to come out of the comments made by the TAST on the strengths of the process were (a) that it was a team approach (three comments), and (b) that it was systematic (five comments).

Comments:

"I liked the team approach."

"Everyone had a chance to be heard and ideas considered."

"A variety of participants meant that different perspectives were covered."

"Clear outlines and guides.” 
“The process to prioritise worked well."

"It systematically isolated the priorities and found the most efficient way to deal with them."

“We developed specific action plans.”

"It made us aware of workloads for teachers and teacher aides."

"Realistic steps to be taken.”

"Teacher aides will feel more informed."

Only three of the team commented on the weaknesses. Two members commented on the time factor and suggested that the school should offer some release time for the TAST to meet. Two members considered that the wording of the indicators could have been clearer as they felt that the school community may have misinterpreted some of them. One team member felt that the weighting of the different constituencies may have skewed the rating results.

Comments:

"Sometimes one group could sway the results."

"People might have interpreted the questions differently to other groups and so responses varied."

"I'm not sure about the validity of the survey."

"There could be a problem with time."

"Resource the release time."

The suggestions for improvement related to clarifying the wording of some of the indicators to minimise misinterpretation.

\section{What impact does the teacher aide planning process have on personnel and students?}

Source: Teacher aide questionnaire, semi structured interviews and permanent products.

Teacher aide questionnaires

The teacher aide questionnaire (Appendix E) was designed by the TAST to ascertain the effectiveness of the action plans and was intended to be completed after the second meeting in week three of term one. It was actually completed after the first round of 
meetings (weeks three and four). There were five returns (71\%). The results are shown in Table 5.7.

Table 5.7. Teacher aide responses to questionnaire.

\begin{tabular}{|c|c|c|c|}
\hline Questions & Yes & No & $\begin{array}{c}\text { Not } \\
\text { Applicable }\end{array}$ \\
\hline $\begin{array}{l}\text { 1. Were you given time to find out about the } \\
\text { teacher, students and the class? }\end{array}$ & 2 & 2 & 1 \\
\hline 2. Did you feel able to collaborate? & 5 & 0 & 0 \\
\hline $\begin{array}{l}\text { 3. Did you feel informed about your role in the first } \\
\text { weeks? }\end{array}$ & 4 & 0 & 1 \\
\hline $\begin{array}{l}\text { 4. Are you clear about your roles and } \\
\text { responsibilities? }\end{array}$ & 4 & 1 & 0 \\
\hline $\begin{array}{l}\text { 5. Do you feel that you have a good understanding } \\
\text { of the students' needs? }\end{array}$ & 5 & 0 & 0 \\
\hline 6. Do you feel familiar with classroom routines? & 5 & 0 & 0 \\
\hline $\begin{array}{l}\text { 7. Do you feel comfortable with communication so } \\
\text { far? }\end{array}$ & 5 & 0 & 0 \\
\hline 8. Do you feel informed about induction procedures? & 5 & 0 & 0 \\
\hline $\begin{array}{l}\text { 9. Do you feel informed about how to access } \\
\text { information regarding training opportunities? }\end{array}$ & 5 & 0 & 0 \\
\hline $\begin{array}{l}10 . \text { Do you feel more informed as a result of this } \\
\text { process than in previous years? (for returning teacher } \\
\text { aides) }\end{array}$ & 3 & 2 & 0 \\
\hline
\end{tabular}

The numbers were too small to allow for meaningful statistical analysis of the data, however, examination of the results indicated a reasonable level of satisfaction amongst the teacher aides at the outcomes of the plans. The exception was the time allocated for teacher/teacher aide meetings. 
Comments included:

"I knew the teacher and students from the previous year."

"I got general info from the SENCO."

"First meeting was a few weeks in."

"Good to have more 1:1 with the teacher."

"Would like more training."

\section{Semi Structured Interviews}

As the researcher, I took some of the categories of impact reported by the schools in the US study (Giangreco et al, 2003) and turned them into a semi structured interview for the TAST (Appendix F). The five team members (excluding the researcher and the parent representative) were given the questions and had the opportunity to consider them before the interview. The interviews were taped and transcribed for data which were used for triangulation purposes. The questions fell into two categories - impact on school personnel and impact on student outcomes.

Impact on school personnel.

1. Did use of the teacher aide action planning guide assist with clarification of roles and responsibilities between teacher aides and other school professionals?

The overall response to this question was a positive one, with all team members commenting on the following outcomes: (a) teachers being more aware of their responsibilities for planning for, and supervision of, teacher aide support, (b) the necessity of an induction process for new teacher aides and, (c) the importance of opportunities for teachers and teacher aides to meet regularly so that roles and responsibilities could be continually assessed.

2. Did use of the teacher aide action planning guide improve morale among teacher aides?

Again the responses were positive. All members of the team were of the opinion that this study, by focussing on teacher aides and their work within the school, had lifted the 
morale of the teacher aides. The teacher aide on the team claimed that their profile had been lifted, and that they were being listened to.

3. Did use of the teacher aide action planning guide increase awareness of teacher aide value amongst the school staff?

Three team members observed that some teachers were more positive about having teacher aides in their classrooms because of this process. This was as a direct result of the self-assessment survey conducted at the beginning of the study that looked at indicators of teacher aide support within the school. Teachers who had little experience of teacher aides were made much more aware of their work. The participants said that those teachers who did have experience of working with teacher aides were already aware of their value and contributed positively to the staff room discussions promoted by the survey.

Impact on Student Outcomes.

4. Did use of the teacher aide action planning guide improve student achievement?

Although it was a little early to say definitively, it was claimed by every member of the team that the school was now more aware of the importance of teacher/teacher aide meetings. There was an expectation from all team members that management would enable staff to organise them in the future. They hoped that the result would be more informed personnel and more effective planning and evaluation and they anticipated that this would lead to improved student achievement. Another point made was that now teacher aides were made more aware of training options, they would have more opportunity to be upskilled in the curriculum and in behaviour management.

5. Did use of the teacher aide action planning guide lead to better inclusion of all students?

All team members considered that the heightened awareness, through use of the action planning guide, of the importance of teachers and teacher aides communicating more effectively by meeting and using log books, clarifying roles and responsibilities and targeting training had led to better inclusion in some instances. A good example of this 
awareness was given by one teacher on the TAST who had organised meetings with the teacher aide and the Itinerant Teacher of the Deaf. The result was that they now had strategies for including that student more effectively within the regular classroom activities whereas previously that student had always been removed from the classroom for her 'teacher aide time'. The rest of the class were also given strategies for inclusion such as facing the student when speaking and using the microphone in shared reading activities.

In connection with teacher/teacher aide communication, the team also commented on the issue of student dependency on teacher aide assistance. Two participants observed that when the adults planned what teacher aide assistance was necessary and how best to deliver that assistance there was more likelihood of responsibility being taken by the teacher for including all students in the classroom programme. There was also less chance of dependency, consistency in behaviour management, more opportunity for group work and more opportunities for the teacher aide to work as an aide to the teacher rather than an aide to the student. It was unclear from the interviews whether this was as a direct result of the planning process or good practice already happening in certain classrooms.

6. Did use of the teacher aide action planning guide lead to a better understanding of the students?

The teacher aide and senior management representatives on the team considered that the improvement in communication of personnel involved with students had led to a better understanding of those students. There was now a prerequisite that teacher aides would read students' IEPs and any relevant notes prior to initial meetings at the start of the school year. All team members judged that pooling knowledge of the students gave everyone a better overview.

7. Did use of the teacher aide action planning guide improve delivery of instruction?

The action planning guide was considered by the whole team to have promoted discussion on the use of learning support plans (Appendix I) and logs sheets for teachers and teacher aides to use to improve communication on a day-to-day basis and so 
improve the delivery of instruction for students with special education needs. Effective methods of day-to-day communication were discussed by teachers and teacher aides at their initial meetings as per plan of action (2) (Appendix M). One teacher in the TAST stated that her weekly plan had reinforced her responsibility for the instruction of all students in her classroom.

8. Did use of the teacher aide action planning guide improve home/school collaboration?

The team unanimously declared home/school collaboration to have been reasonably effective already, but considered that the inclusion of a parent representative in the TAST and parent input into the self assessment survey, gave the team a better parent perspective on teacher aide supports.

9. Did use of the teacher aide action planning guide increase peer interactions?

When asked this question, the general opinion from all the team members was that the move towards improved communication between school professionals and teacher aides had raised awareness of the teacher aide role in including students with special education needs in regular classrooms. In particular, the role of the teacher aide as a facilitator of improved peer interactions i.e. knowing when to step back, including peers in activities etc. It was considered by the team that students with special education needs were not so isolated and had more confidence in interacting with their peers.

\section{Suggestions for Future Directions}

In reply to the question, “Where to next?”, team members unanimously stated their disappointment at the decision to take out the teacher aide section of the "Teacher Only" day at the beginning of the year and expressed their commitment to ensuring that it be included in next year's agenda. The teacher aide on the team commented that such a meeting would be beneficial at the start of every term.

The teachers on the team confirmed the usefulness of the teacher/teacher aide meetings that had occurred during the first weeks of term and stated that those meetings had proved to be so valuable that they intended to ensure that there would be more 
throughout the year. The teachers planned to use some of the ideas brainstormed during the problem-solving sessions at the TAST meetings. Ideas such as: (a) the use of assembly time, (b) the use of some of the students' allocated "teacher aide time" and, (c) teacher aides accumulating time by starting late or finishing early.

One teacher suggested that classes should be finalised by the end of Term 4 for the following year, and teachers should know whether they were to have teacher aide support and who that teacher aide would be. This would then enable them to get together and forward plan. This had also been suggested at a TAST meeting. She went on to say that status needed to be given to these meetings, and to teacher aides, to acknowledge all the work that they do. A quote from one of the team was, "If you can just come up with the time, then lots of the other stuff will just fall into place...things can be discussed and worked out and managed.”

Suggestions for teachers - both generic and more specific to certain students - on how best to use teacher aide support was another definite idea to come out of this process. The SENCO observed, "we are not asking people to work harder, we are asking them to work smarter." In connection with this - it was also suggested that there be one or two staff meetings a year put aside to address teacher aide issues. Issues such as planning, evaluating and supervising the work of teacher aides in the classroom. These staff meetings could double up as information sessions on the work that the teacher aides are doing in the school - presented, possibly, by the teacher aides themselves.

The TAST considered that their formation, subsequent regular meetings throughout the year and the system used (The NZ Guide) had led to the creation of positive ideas. They said that it had "raised awareness of teacher aide support forever!" They intended to keep the team together to make plans of action for other indicators that needed work and also to look at other aspects of inclusion. 


\section{CHAPTER SIX}

\section{Discussion}

\section{Comparison with the US Study}

This study replicated a study conducted in the United States by Dr. Michael Giangreco and his team (Giangreco et al., 2003) with one or two differences. The major difference being that the US study was conducted in 46 self-selected schools over 13 states, whereas the New Zealand study was conducted in one volunteer school only.

The NZ study followed the same process as outlined in The Guide but differed inasmuch as the initial survey of the school's status on the 28 indicators of teacher aide support was administered to all adult school personnel and not just to the voluntary team. The overall results of the self-assessments in the US study showed that $50-96 \%$ of the schools in the study considered that 21 of the 28 indicators needed "major" or "some” work. As can be seen in the results, the NZ school had a much higher level of satisfaction with its teacher aide support with only 2 of the 28 indicators rating over $50 \%$ overall in the combined "needs work" categories. However no conclusions can be drawn from this due to the small size of the study.

The TAST simply accepted the six highest rated indicators in the combined "needs work” categories (with some consideration for the teacher aide constituency results) as their top six priority indicators. The schools in the US study did not necessarily choose the highly rated indicators in the combined "needs work" categories as their top priority indicators.

As the researcher in the NZ study, I used the same indicators (using NZ terminology) and the same individual team member questionnaire to ascertain opinions on whether the process did what it purported to do, what perceived strengths and weaknesses existed within the process and whether TAST had any suggestions for improvement. The US study required the school teams to give a report on the impact of the process on school personnel and student outcomes. I took the themes which emerged from the impact reports in the US study and used them as a basis for semi-structured interviews 
with the TAST and added a teacher aide questionnaire to collect data on the effectiveness of the plans of action.

However, despite these differences, there were many similarities in outcomes. As with the US study, the data presented in this NZ study showed that The Guide was successfully utilised to self-assess the school's status on indicators of teacher aide support, identify priorities and make corresponding plans of action. As in the US study, it was found that the process did what it purported to do and the TAST considered it helpful, logical and easy to use. The actions were well planned and although there were some difficulties in implementation, the TAST considered that the process had had a positive impact on the adults and that, in turn, had led (and would lead) to positive student outcomes, such as improvements in achievement, inclusion, behaviour and peer interactions.

\section{Action Rankings}

There were also similarities in the indicators which were action ranked highly by the teams in the US and the indicators chosen to act upon by the TAST. Of the top three indicators chosen to act upon by schools in the US study, two were also chosen in the NZ study -times and mechanisms to work with teachers and, orientation and entry-level training.

Relief teacher aides recruited and trained had the highest overall combined percentage scores in the "needs major work" and "needs some work" categories in both studies, (and by the teacher aide constituency), but was not chosen to work on at all by the NZ team and only by five of the 46 school teams in the US study. Therefore, even though it was priority ranked fourth in the US study, it dropped to ninth in action ranking.

Accurate job descriptions, which had ranked highly in both priority and actions in the US study, priority ranked only joint seventeenth in the NZ study in the overall results however the teacher aide constituency did priority rank it jointly third with 50\% considering that it needed "major" or "some” work. I considered that this discrepancy could be due to a lack of communication stemming from a lack of times and mechanisms for teacher/teacher aide meetings. 
Evaluate impact of teacher aide services had high percentage scores in both studies sixth highest in the US study and jointly fourth in the NZ study. This indicator also dropped in action ranking in the US study and was postponed in the NZ study.

It is my belief that choices made by the TAST, on which indicators to action, could be considered "first generation" issues and those that were low in the action ranking could be considered “second generation” issues, as noted previously by Giangreco et al (2003). First generation issues being those that were considered to be the most basic, for example, meeting times, training and orientation. Until these issues have been addressed, it is unlikely that the school will look at second generation issues such as training relief teacher aides, teacher aide assignment to classrooms or evaluating teacher aide services. Factors such as perceived ease or difficulty of implementation, time, immediacy of the need, and perceived locus of control affected the relationship between needs, priorities and actions taken.

\section{Priorities versus Actions}

The top ranked priority was relief teacher aides recruited and trained, however the team were reluctant to take action on this issue as they considered that they had no control over the employment of these personnel once they were trained and did not want to be involved in producing a training programme. The team considered that the main reason this indicator had ranked so highly in the overall combined "needs major work" and "needs some work" categories was simply the fact that there are no relief teacher aides in New Zealand. The school is expected to deal with teacher aide absences within its systems, by relocating students or other teacher aides. In some instances parents are asked to come in or to keep their children at home.

As discussed in the literature (French, 1998), if the teacher aides were truly an aide to the teacher rather than an aide to the student, involving families to help out would be less likely to occur. There is also an issue of equity here - these requests would never be made to the family of a student who did not have special education needs. Rutherford (2002) has made a recommendation "that all schools/regions broaden their existing pools of relieving teachers to include teacher aides” (p.42). This would make the relieving situation much more equitable. 
A second highly ranked priority, evaluate impact of teacher aide services, was postponed to a later time, even though the team stated that it would not take long to plan. The team claimed that there were already some good systems in place that could be used to evaluate - they cited IEPs, student records on reading and maths levels, and comparison of student academic and social behaviours with and without teacher aide supports. The reasons given for postponement were the perceived difficulty in implementation and the perceived possible sensitivity of the issue with regards to competency.

The AC Nielson survey (2001) showed that a high percentage of the Special Education Grant in New Zealand was spent on teacher aide hours. However, there appears to be no accountability of the effectiveness of this costly resource either nationally or, in this case, at school level. Giangreco et al (2001) also made this point when they stated that teacher aide support of students with special education needs remains "one of the least studied and potentially most significant aspects of special education over the past decade.” (p.45.)

A third highly ranked priority was put aside because the school staff on the TAST judged that there had been a misinterpretation of the indicator by the school community when they ranked it as the third highest priority. The indicator was teacher aides assigned to classrooms rather than 1:1. This judgement was based on the opinions of the TAST that teacher aides were very rarely assigned to work solely 1:1 with students in their school except in circumstances where the student had particular high needs such as Braille assistance or toileting. It was their belief that the community had simply registered their agreement with the indicator - that being assigned to a classroom as opposed to 1:1 was the best way for teacher aides to work. There is no logical explanation for why the TAST decided that this was the case in this instance, but not for any of the other indicators. As the researcher, I interpreted the response, at the time, to be defence for the way the teacher aides were currently assigned within the school, as was demonstrated in the TAST's response to the relief teacher aides issue.

In retrospect, I consider that my decision to use the wording of the indicators in The Guide (made NZ user-friendly), in an attempt to stay as true to the original as possible, may not have been the best course to take. Perhaps more time spent at the beginning of the process on interpreting the indicators and, as Giangreco et al (2003) suggested, 
ensuring that the process was "meaningfully individualised” (p.66) may have overcome the TAST's perceptions of misinterpretation.

The final, first generation, choices made by the TAST were times and mechanisms to work with teachers and, orientation and entry-level training. These were considered to be good starting points, within their sphere of influence and would not significantly add to their workload.

It transpired that the main actions taken centred around the times and mechanisms issue, with the orientation and entry-level training restricted to updating the orientation checklist (Appendix $\mathrm{H}$ ) and making certain that all teacher aides were aware of the induction procedures and opportunities for training.

In the evaluation of Kia Tutangata ai - Supporting Learning (Cameron \& Wylie, 2002), a report on this New Zealand Ministry of Education initiative, the issue of times and mechanisms was identified by a significant number of schools as being the area most in need of development. The report suggested that the professional development providers introducing the resource into schools nationwide should "provide real life examples of ways that schools have found to create time to plan with teachers within current school resources” (p.14). As one of the providers, I experienced this recurring theme in the majority of schools in which I worked - both primary and secondary.

It became apparent during the delivery of Kia Tutangata ai - Supporting Learning (Ministry of Education, 2002) and from the literature review for this dissertation that the issue of times and mechanisms for teachers and teacher aides to meet is inseparable from the issue of supervision of teacher aides. As French and Pickett (1997) noted, when professionals begin to recognise that supervising teacher aides is an important part of their work, then they will begin to solve the problem of when to meet.

As the issue of times and mechanisms for teachers and teacher aides to meet was the main thrust of the TAST's plans and actions, this in turn influenced the results of the impact of the process. It follows that the reported impact will relate to issues chosen. 


\section{Implementation of Plans}

According to the results, the TAST deemed The NZ Guide to be effective in assisting them to self-assess the school's needs in regard to teacher aide supports, prioritise, and develop plans of action for addressing the two identified needs. However when it came to implementation of those plans of action there were several circumstances outside the control of the TAST which led to changes of action.

The most notable change of action was as a result of a decision, taken at senior management level, to reduce the "Teacher Only" days at the start of the school year from two days to one day. The effect was that some items on the "Teacher Only" day agenda had to be dropped. One of the first to go was the teacher aide slot planned prior to and including, lunch. This decision gave the impression that enabling teachers to meet with teacher aides prior to the start of the school year was not seen as a priority by senior management. This impression was indeed unfortunate as, according to the responses in the interviews, the focus on the teacher aides had been a positive experience throughout the year. The teacher aides had felt valued, appreciated and recognised. Release time during the first weeks was promised for the teachers and teacher aides to meet. This proved to be difficult logistically, and, as pointed out by one of the TAST, teachers do not like to be away from their classes early in the year as it is an important time for consolidation.

Senior management had been represented on the TAST by the Deputy Principal to ensure that they were informed of, and approved of, proposed plans of action. Her decision to retire at the end of 2003 was not anticipated to cause any changes of plan. However, added to the other factors (teacher only day reduction, drop in staffing, change of SENCO role), it was necessary to make changes. This highlights the reality that when conducting research in the real life environment of a school it is extremely difficult, if not impossible, to control all the variables. 


\section{Limitations}

There were three main limitations to this study. The first was its size - only one school was used to trial The NZ Guide. Although similarities could be drawn between the NZ results and those of the US study which used a variety of schools across wide geographical and socio-economic settings, there cannot be any assumptions made that the results would be similar if The NZ Guide was used in another New Zealand primary school.

The second limitation was the time allocated for the research meant that the impact of the actions could only be gauged in an immediate way. Long term impact could only be anticipated. However, responses to the questionnaires and statements made during the interviews indicated that the participants perceived that the school's involvement in the teacher aide planning process had been worthwhile.

The third limitation was the small representation of the school community in the TAST - this was necessary to facilitate the smooth running of the meetings. However, in order to make significant changes to teacher aide support, it would have been more effective to have had the principal on the team. This may also have given the team more status. A more significant "ripple effect” (Giangreco et al., 2003, p.76) may also have occurred, that is, more school personnel outside of the team may have supported the plans of action. The parent voice was limited too as the parent who volunteered was unable to complete the process.

\section{Conclusions and Implications}

Perceptions of what a teacher aide is, and what, exactly, it is that they do, vary from person to person, school to school. A guide, such as the one used in this study can help to clarify the roles and responsibilities of teacher aides and clarify the support that they provide within a school. The flexibility of The Guide allows schools to personalise the indicators to fit their particular setting. The Guide’s interactive design provides a structure for a team to problem solve and make decisions. As it is freely availably from the University of Vermont website, it is accessible to all schools at no cost. 
It is my intention to use this process in other schools in my RTLB cluster and collect data on the effectiveness of the process, the self-assessment results, the priority rankings, actions taken and the impact of those actions on the school personnel and student outcomes. Such information could be used for further research into this process in New Zealand schools.

Highly ranked priorities could also be used as the basis for further research, for example, investigation into the evaluation of the effectiveness of teacher aide support within schools for both teachers and students, role clarification, supervision and written plans, or the effectiveness of teacher/teacher aide training "in school” and its impact on student outcomes.

This study concludes with two recommendation made by Giangreco et al (2003). First, that schools use The Guide for a sustained cycle of planning, implementation and evaluation, so that early successes can be built on and more complex second generation issues addressed. However, there is a caution to educators, that whilst strengthening teacher aide support is extremely valuable, it could inadvertently interfere with providing students with disabilities with a “free, appropriate education” (p.78).

Therefore, the second recommendation is that schools think of the teacher aide planning process as supportive of one of two main tracks for improving services for students with special education needs in the regular school setting, the second track being that schools should investigate ways in which students with special education needs could receive more of their instruction from qualified teachers, and any other specialists, alongside their same age peers in the context of the regular classroom setting.

Investigation into the second track could include many of the strategies promoted by Resource Teachers of Learning and Behaviour (RTLB). Strategies such as cooperative learning, peer support, mentoring and co-teaching. Attending to both tracks may lead to more positive outcomes for students with special education needs and reduce some of the risks associated with the over utilisation or inappropriate utilisation of teacher aide supports.

This was a single case study and results cannot be generalised in any certain way to other schools in New Zealand. However, the similarities to many of the findings in the US study would indicate that there are common issues in all schools, despite differences 
in administrative and educational systems. The teacher aide resource in New Zealand, for students with special education needs, is a costly and significant one - this study has contributed towards research into how best to utilise this valuable resource. 


\section{References}

AC Nielson. (2001). Teacher Aide Professional Development Survey: Report prepared for Wellington College of Education (Unpublished report). Wellington: AC Nielson.

Avramidis, E., Bayliss, P., \& Burden, R. (2000). A survey into mainstream teachers' attitudes towards the inclusion of children with special education needs in the ordinary school in one local education authority. Educational Psychology, 20(2), 191-211.

Ballard, K., \& MacDonald, T. (1998). New Zealand: Inclusive school, inclusive philosophy? In T. Booth \& M. Ainscow (Eds.), From them to us: an international study of inclusion in education. (pp. 68-94). London: Routledge.

Blacock, G. (1991). Paraprofessionals: Critical team members in our special education programs. Intervention in School and Clinic, 26(4), 200 - 214.

Boomer, L. W. (1994). The utilization of paraprofessionals in programs for students with autism. Focus on Autistic Behaviour, 9(2), 1-9.

Booth, T., \& Ainscow, M. (1998). New Zealand response: One philosophy or two? In T. Booth \& M. Ainscow (Eds.), From them to us: An international study of inclusion in education (pp. 95-100). London: Routledge.

Brown, L., Farrington, K., Knight, T., Ross, C., \& Ziegler, M. (1999). Fewer paraprofessionals and more teachers and therapists in educational programs for students with significant disabilities. TASH, 24(4), 250-253.

Cameron, M., \& Wylie, C. (2002). Evaluation of the introductory professional development programme for teacher aides/kaiawhina supporting teachers of students with special education needs. Wellington: NZCER.

Clark, C., Dyson, A., Millward, A., \& Robson, S. (1999). Theories of inclusion, theories of schools: Deconstructing and reconstructing the 'inclusive school'. British Educational Research Journal, 25(2), 157-177.

Couper, L. J. D. (2003). Kia tutangata ai-supporting learning. New Zealand Education Gazette, 82(1), 1-2.

Department of Education. (1988). Draft Review of Special Education. Wellington: Department of Education.

Department of Education. (1989). The charter framework. Wellington: Department of Education.

Downing, J. E., Ryndax, D. L., \& Clark, D. (2000). Paraeducators in inclusive classrooms: Their own perceptions. Remedial and Special Education, 21(3), 171-181.

Doyle, M. B. (2002). The paraprofessional's guide to the inclusive classroom: Working as a team. (2nd ed.). Baltimore: Paul H. Brookes. 
Ferguson, D. L. (1995). The real challenge of inclusion: Confessions of a "rabid inclusionist". Phi Delta Kappan, 77(4), 281-287.

French, N. K. (1998). Working together: Resource teachers and paraeducators. Remedial and Special Education, 19(6), 357-369.

French, N. K. (1999). Paraeducators: Who are they and what do they do? Teaching Exceptional Children, 32(1), 65-69.

French, N. K., \& Chopra, R. V. (1999). Parent perspectives on the roles of paraprofessionals. JASH, 24(4), 259-272.

French, N. K., \& Pickett, A. L. (1997). Paraprofessionals in special education: Issues for teacher education. Teacher Education and Special Education, 20(1), 61-73.

Freschi, D. F. (1999). Guidelines for working with one-to-one aides. Teaching Exceptional Children, 31(4), 42-45.

Friend, M., \& Cook, L. (2000). Interactions: Collaboration skills for school professionals (3rd ed.). New York: Addison Wesley Longman, Inc.

Giangreco, M. F. (1993). Teamwork and support services in the education of students with disabilities. Paper presented at the Special Education Service Inaugural Conference, Dunedin, New Zealand.

Giangreco, M. F., Baumgart, D. M. J., \& Doyle, M. B. (1995). How inclusion can facilitate teaching and learning. Intervention in School and Clinic, 30(5), 273278.

Giangreco, M. F., Broer, S. M., \& Edelman, S. W. (1999). The tip of the iceberg: Determining whether paraprofessional support is needed for students with disabilities in general education settings. JASH, 24(4), 281 - 291.

Giangreco, M. F., Broer, S. M., \& Edelman, S. W. (2001a). Schoolwide planning to improve paraeducator supports: A pilot study. Rural Special Education Quarterly, 21(1).

Giangreco, M. F., Broer, S. M., \& Edelman, S. W. (2001b). Teacher engagement with students with disabilities: Differences between paraprofessional service delivery models. JASH, 26(2), 75-86.

Giangreco, M. F., CichoskiKelly, E., Backus, L., Edelman, S. W., Tucker, P., Broer, S., et al. (1999, March 1999). Developing a shared understanding: Paraeducator supports for students with disabilities in general education. TASH Newsletter, 21-23.

Giangreco, M. F., \& Doyle, M. B. (2002). Students with disabilities and paraprofessional supports: Benefits, balance and band-aids. Focus on Exceptional Children., 34(7), 1-12. 
Giangreco, M. F., Edelman, S., Evans-Luiselli, T., \& MacFarland, S. Z. C. (1997). Helping or hovering? Effects of instructional proximity on students with disabilities. Exceptional Children, 64(1), 7-18.

Giangreco, M. F., Edelman, S. W., \& Broer, S. M. (2001a). A guide to schoolwide planning for paraeducator supports. Burlington, VT: Center on Disability \& Community Inclusion. University of Vermont.

Giangreco, M. F., Edelman, S. W., \& Broer, S. M. (2001b). Respect, appreciation, and acknowledgement of paraprofessionals who support students with disabilities. Exceptional Children, 67(4), 485-498.

Giangreco, M. F., Edelman, S. W., \& Broer, S. M. (2003). Schoolwide planning to improve paraeducator supports. Exceptional Children, 70(1), 63-79.

Giangreco, M. F., Edelman, S. W., Broer, S. M., \& Doyle, M. B. (2001c). Paraprofessional support of students with disabilities: Literature from the past decade. Exceptional Children, 68(1), 45-63.

Idol, l., \& West, J. F. (1991). Educational collaboration: A catalyst for effective schooling. Intervention in School and Clinic, 27(2), 134-142.

Jones, K., \& Bender, W. (1993). Utilization of paraprofessionals in special education : A review of the literature. Remedial and Special Education, 14(1), 7-14.

Karagiannis, A., Stainback, W., \& Stainback, S. (1996). Rationale for inclusive schooling. In W. Stainback \& S. Stainback (Eds.), Inclusion: A guide for educators. Baltimore: Paul Brookes.

Kauffman, J. K. (1993). How we might achieve the radical reform of special education. Exceptional Children, 60(1), 6-16.

Kavermann, A., \& Bourke, R. (1998). Creating inclusive practices in secondary school settings: Issues and challenges. Retrieved March, 2002, from http://www.intra.ses.org.nz/sesinfo/sesdocs/conference98/kavermann.htm

Lange, D. (1988). Tomorrow's Schools. Wellington: New Zealand Government Printer.

Lipsky, D. K. (2003). The coexistence of high standards and inclusion. School Administrator, 60(3), 32-36.

Marks, S. U., Schrader, C., \& Levine, M. (1999). Paraeducator experiences in inclusive settings: Helping, hovering, or holding their own? Exceptional Children, 65(3), 315-328.

McLesky, J., \& Waldron, N. (1998). Responses to questions teachers and administrators frequently ask about inclusive school programmes. SET, 2(12), 1-4.

Meyer, L. H., \& Bevan-Brown, J. (2000). Supporting social relationships: Partnerships and friendships. In D. Fraser, R. Moltzen \& K. Ryba (Eds.), Learners with special needs in Aotearoa New Zealand (pp. 147-180). Palmerston North, New Zealand: Dunmore Press. 
Ministry of Education. (1993). The New Zealand curriculum framework. Wellington: Ministry of Education.

Ministry of Education. (1995). Special education policy guidelines. Wellington: Ministry of Education.

Ministry of Education. (1996). Special education 2000. Wellington: Ministry of Education.

Ministry of Education. (1997, November 2003). National education guidelines. Retrieved May, 2004, from http://www.minedu.govt.nz/index.cfm?layout=document\&documentid=8221\&d $\underline{\text { ata }=1}$

Ministry of Education. (1999). Special education policy guidelines. Wellington: Ministry of Education.

Mitchell, D. (1999). Special Education in New Zealand: A decade of change. New Zealand Journal of Educational Studies., 34(1), 199-210.

Mitchell, D. (2000). Policies and systems for students with special education needs. In D. Fraser, R. Moltzen \& K. Ryba (Eds.), Learners with special needs in Aotearoa New Zealand (2nd ed.). Palmerston North: Dunmore Press.

Moore, D., Anderson, A., Timperley, H., Glynn, T., Macfarlane, A., Brown, D., et al. (1999). Caught between stories: Special education in New Zealand. Wellington: New Zealand Council for Educational Research.

Morgan, J., Hofmeister, A., \& Ashbaker, B. (1995). Training programs for paraeducators in the United States. A review of the literature. Logan: Utah State University.

Moshoyannis, T., Pickett, A. L., \& Granick, L. (1999). The evolving roles and education/training needs of teacher and paraprofessional teams in New York City public schools.

New Zealand Educational Institute. (1995). Breaking new ground: Support staff in today's schools. Wellington, New Zealand: NZEI.

New Zealand Ministry of Education. (2002). Kia tutangata ai - supporting learning. Wellington: Learning Media.

O'Neill, J. (1995). Can inclusion work? A conversation with Jim Kauffman and Mara Sapon-Shevin. Educational Leadership,, 52(4), 7-11.

Parnes, S. J. (1997). Optimize the magic of your mind. Buffalo, NY: The Creative Education Foundation in association with Bearly Limited.

Pickett, A. L. (1996). A state of the art report on paraeducators in education and related services. New York: National Resource Center for Paraprofessionals in 
Education and Related Services, Center for Advanced Study in Education, The Graduate School and University Center, City University of New York.

Pickett, A. L. (1999). Paraeducators: Factors that influence their performance, development and supervision. Retrieved October, 2001, from http://ericec.org/digests/e587.htm.

Pickett, A. L., \& Gerlach, K. (1997). Supervising paraeducators in school settings. A team approach. Austin TX: Pro Ed Inc.

Rutherford, G. (2002). Getting a fair go? Issues and practices regarding teacher aide support of students with disabilities. Dunedin: Dunedin College of Education.

Safarik, L. (1997). Team roles in instructional settings. In A. L. Pickett, \& Gerlach, K (Ed.), Supervising paraeducators in school settings. A team approach (1st ed., pp. 25-50). Austin: PRO-ED, Inc.

Salzberg, C. L., \& Morgan, J. (1995). Preparing teachers to work with paraeducators. Teacher Education and Special Education, 18(1), 49-55.

Shukla, S., Kennedy, C. H., \& Cushing, L. S. (1999). Intermediate school students with severe disabilities: Supporting their social participation in general education classrooms. Journal of Positive Behaviour Interventions, 1(3), 130-140.

Skrtic, T. M. (1995). The special education knowledge tradition: Crisis and opportunity. In F. L. Meyen \& T. M. Skrtic (Eds.), Special education and student disability: An introduction. (4th ed., pp. 569-607). Denver, CO: Love Publishing Company.

Thomson, C. (1998, July). Inclusion and professional development for resource teachers. Paper presented at the Australian Teachers Education Association. 28th Annual Conference., Melbourne, Australia.

Thomson, C., Brown, D., Jones, E., \& Manins, E. (1999). The development of resource teachers in New Zealand: A quarter century of paradigm change. In I.

Livingstone (Ed.), New Zealand Annual Review of Education. Wellington: Victoria University of Wellington.

Thorburn, J. (2001). Teacher aides and their professional development and support needs: A literature review. (Unpublished report). Auckland: Auckland College of Education.

Villa, R. A., Thousand, J. S., Nevin, A. I., \& Malgeri, C. (1996). Instilling collaboration for inclusive schooling as a way of doing business in public schools. Remedial and Special Education, 17(3), 169-181.

Wadsworth, D., \& Knight, D. (1996). Paraprofessionals: The bridge to successful full inclusion. Intervention in School and Clinic, 31(3), 166-171.

Wallace, T., Bernhardt, J., \& Utermarck, J. (1999). Minnesota paraprofessional guide. St. Paul, MN: Institute on Community Integration, University of Minnesota. 
Wylie, C. (2000). Picking up the pieces. A review of special education 2000. Wellington: NZCER.

Ysseldyke, J. E., \& Christensen, S. (1993). TIES 11: The instructional environment system: 11. Longmont, CO: Sopris West. 


\section{APPENDICES}


3. Have the team assess their own status and fact-find in relation to the six teacher aide topics:

\section{Self-Assessment}

As a team: (a) rate your school's performance on each numbered statement (1-28); and (b) rate your school's performance on each of the six areas major headings (A-F). List additional relevant facts you already have or need to get.

Check one box for each statement

\begin{tabular}{|c|c|c|c|c|}
\cline { 2 - 4 } \multicolumn{1}{c|}{$A}$. & $\begin{array}{c}\text { Needs } \\
\text { Major Work }\end{array}$ & $\begin{array}{c}\text { Needs } \\
\text { Some Work }\end{array}$ & $\begin{array}{c}\text { OK } \\
\text { for now }\end{array}$ & $\begin{array}{c}\text { Doing } \\
\text { Well }\end{array}$ \\
\hline Acknowledging Teacher Aides & &
\end{tabular}

1. Teacher aides should be considered members of the educational teams corresponding to their work assignments. These teams typically consist of the student (when appropriate), the student's parents, teachers, special educators, and others as needed on an ongoing or situational basis (e.g., related services providers, school nurse, older mentors with the same disability as the student).

2. Teacher aides provide important services, under the supervision of a registered teacher, that influence student learning, social/emotional development, and inclusion.

3. Teacher aldes should be valued, appreciated, and recognized for their unique competencies, hard work, and contributlons to the classroom, school, and community.

\section{Other Relevant Facts:}




\begin{tabular}{|c|c|c|c|c|}
\hline \multirow[b]{2}{*}{ B. } & \multicolumn{4}{|c|}{ Check one box for each statement } \\
\hline & \begin{tabular}{|c|} 
Needs \\
Major Work \\
\end{tabular} & $\begin{array}{c}\text { Needs } \\
\text { Some Work }\end{array}$ & $\begin{array}{c}\text { OK } \\
\text { for now }\end{array}$ & $\begin{array}{l}\text { Doing } \\
\text { Well }\end{array}$ \\
\hline \multicolumn{5}{|l|}{$\begin{array}{l}\text { Orienting \& Training } \\
\text { Teacher Aides }\end{array}$} \\
\hline $\begin{array}{l}\text { 4. Teacher aides should receive } \\
\text { orientation (e.g., information about } \\
\text { the student, classroom, and school) } \\
\text { and entry-level training prior to } \\
\text { working directly with students (e.g., } \\
\text { teamwork, inclusive education, roles } \\
\text { and responsibilities of team members, } \\
\text { principles of learning). }\end{array}$ & & & & \\
\hline \multicolumn{5}{|l|}{$\begin{array}{l}\text { 5. Teacher aides should receive } \\
\text { ongoing, on-the-job, training to match } \\
\text { their specific job responsibilities and } \\
\text { assignments. }\end{array}$} \\
\hline \multicolumn{5}{|l|}{$\begin{array}{l}\text { 6. Teacher aides should have access to } \\
\text { ongoing learning opportunities, in } \\
\text { addition to their on-the-job } \\
\text { experiences (e.g., workshops, courses, } \\
\text { internet study) that promote their skill } \\
\text { development in relevant areas (e.g., } \\
\text { supporting students with challenging } \\
\text { behaviors; approaches to literacy; use } \\
\text { of technology; needs of students with } \\
\text { mild to moderate disabilities) and } \\
\text { have input into what training they } \\
\text { need. }\end{array}$} \\
\hline $\begin{array}{l}\text { 7. Teacher aide training experiences } \\
\text { should be designed to allow } \\
\text { individuals to gain continuing } \\
\text { education or college/university } \\
\text { credit. }\end{array}$ & & & & \\
\hline \multicolumn{5}{|l|}{ Other Relevant Facts: } \\
\hline
\end{tabular}




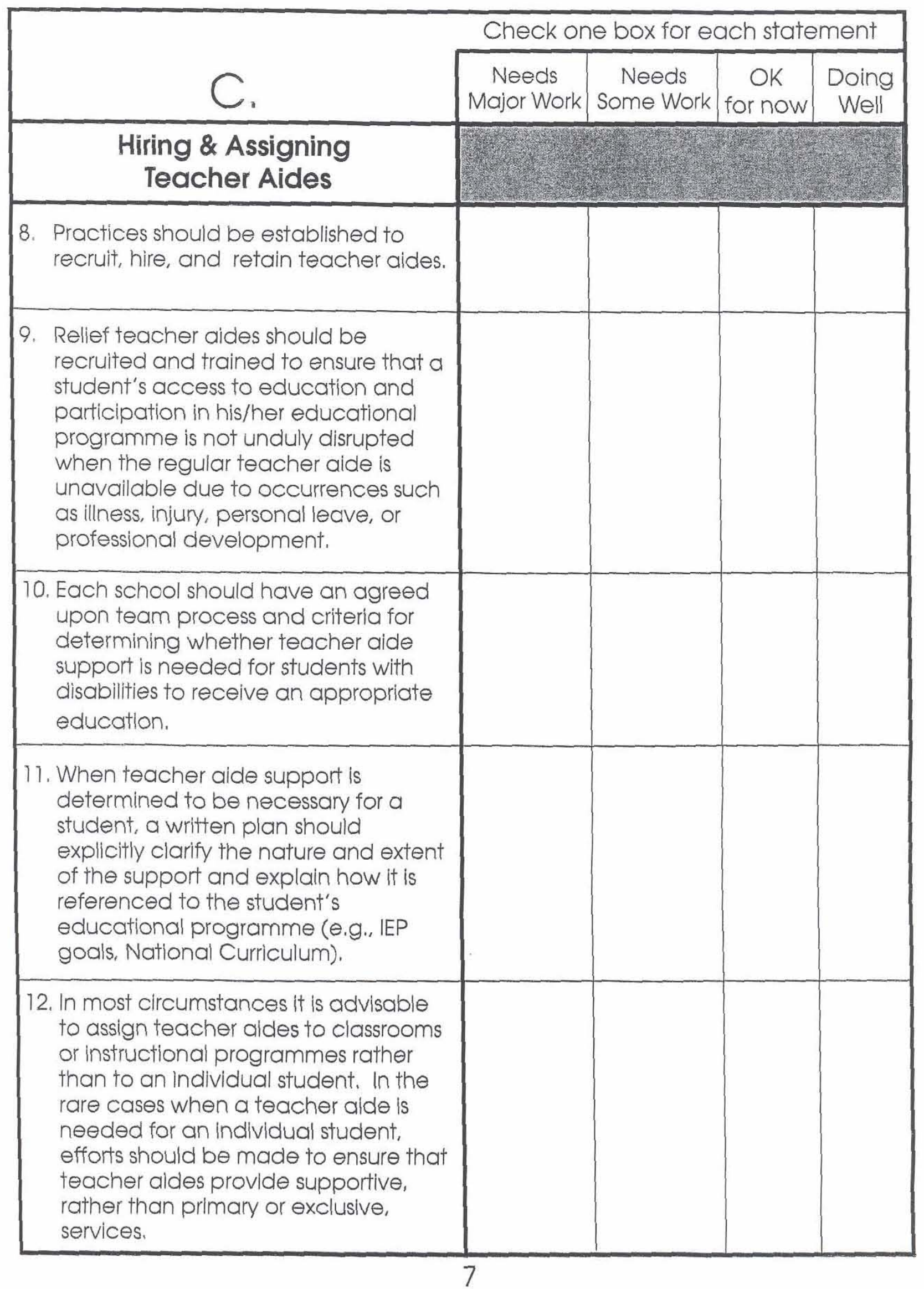




\begin{tabular}{|c|c|c|c|c|}
\hline & \multicolumn{4}{|c|}{ Check one box for each statement } \\
\hline & $\begin{array}{c}\text { Needs } \\
\text { Major Work }\end{array}$ & $\begin{array}{c}\text { Needs } \\
\text { Some Work }\end{array}$ & $\begin{array}{c}\text { OK } \\
\text { for now }\end{array}$ & $\begin{array}{l}\text { Doing } \\
\text { Well }\end{array}$ \\
\hline \multicolumn{5}{|l|}{$\begin{array}{c}\text { Hiring \& Assigning } \\
\text { Teache Aides (continued) }\end{array}$} \\
\hline $\begin{array}{l}\text { 13. When SENCO/management are } \\
\text { making work assignments and } \\
\text { reassignments to meet students' } \\
\text { educational needs, it is advisable to } \\
\text { gain input directly from teacher } \\
\text { aides and other team members } \\
\text { (e.g., parents, teachers, special } \\
\text { educators, related services } \\
\text { providers) to understand factors that } \\
\text { may influence job performance, job } \\
\text { satisfaction, and reduce burnout } \\
\text { (e.g., variety of duties, interpersonal } \\
\text { dynamics, individual skills and } \\
\text { interests, longevity with a particular } \\
\text { student). }\end{array}$ & & & & \\
\hline \multicolumn{5}{|l|}{$\begin{array}{l}\text { 14. Teacher aides should have an } \\
\text { accurate job description that } \\
\text { outlines their roles and responsibilities. } \\
\text { This job description should be } \\
\text { commensurate with the teacher } \\
\text { aide's skill level as it pertains to } \\
\text { students both with and without } \\
\text { disabilities. }\end{array}$} \\
\hline \multicolumn{5}{|l|}{$\begin{array}{l}\text { 15. Teacher aides should be } \\
\text { compensated in accordance with } \\
\text { their level of educatlon, training, } \\
\text { experience, and skills. }\end{array}$} \\
\hline \multicolumn{5}{|l|}{ Other Relevant Facts: } \\
\hline
\end{tabular}




\begin{tabular}{|c|c|c|c|c|}
\hline \multirow[b]{2}{*}{ D. } & \multicolumn{4}{|c|}{ Check one box for each statement } \\
\hline & $\begin{array}{c}\text { Needs } \\
\text { Major Work }\end{array}$ & $\begin{array}{c}\text { Needs } \\
\text { Some Work }\end{array}$ & $\begin{array}{c}\text { OK } \\
\text { for now }\end{array}$ & $\begin{array}{l}\text { Doing } \\
\text { Well }\end{array}$ \\
\hline \multicolumn{5}{|l|}{$\begin{array}{c}\text { Teacher Aide Interactions } \\
\text { with Students \& Staff }\end{array}$} \\
\hline \multicolumn{5}{|l|}{$\begin{array}{l}\text { 16. Teacher aides are expected to } \\
\text { demonstrate constructive } \\
\text { interpersonal skills with students and } \\
\text { other team members (e.g., use } \\
\text { respectful communication when } \\
\text { speaking with or about others; } \\
\text { maintain confidentiallity; ensure } \\
\text { dignity when providing personal } \\
\text { care). }\end{array}$} \\
\hline $\begin{array}{l}\text { 17. Teacher aides should develop and } \\
\text { demonstrate attitudes and work } \\
\text { habits that encourage: student } \\
\text { independence; foster appropriate } \\
\text { interdependence; promote inclusion } \\
\text { and peer interactions; enhance each } \\
\text { students' self-image; and prevent the } \\
\text { unintended negative effects often } \\
\text { associated with the potential over } \\
\text { involvement and proximity of adults. }\end{array}$ & & & & \\
\hline \multicolumn{5}{|l|}{ Other Relevant Facts: } \\
\hline
\end{tabular}




\begin{tabular}{|c|c|c|c|c|}
\hline \multirow[b]{2}{*}{ E. } & \multicolumn{4}{|c|}{ Check one box for each statement } \\
\hline & $\begin{array}{c}\text { Needs } \\
\text { Major Work } \\
\end{array}$ & $\begin{array}{c}\text { Needs } \\
\text { Some Work }\end{array}$ & $\begin{array}{c}\text { OK } \\
\text { for now }\end{array}$ & $\begin{array}{l}\text { Doing } \\
\text { Well }\end{array}$ \\
\hline \multicolumn{5}{|l|}{$\begin{array}{c}\text { Roles \& Responsibilities } \\
\text { of Teacher Aides }\end{array}$} \\
\hline $\begin{array}{l}\text { 18. Within the classroom, on a day-to- } \\
\text { day basis, the classroom teacher is } \\
\text { the instructional leader and } \\
\text { interacts directly on an ongoing basis } \\
\text { with students who have } \\
\text { disabilities. Teacher aides function as } \\
\text { a vital support to students under the } \\
\text { direction of the teacher and special } \\
\text { educators. }\end{array}$ & & & & \\
\hline $\begin{array}{l}\text { 19. Teachers, special educators, and } \\
\text { related services providers (e.g., } \\
\text { speech/language therapists, } \\
\text { physiotherapists, occupational } \\
\text { therapists, school psychologists) have } \\
\text { the ultimate responsibility for ensuring } \\
\text { the appropriate design, } \\
\text { implementation, and evaluation of } \\
\text { instruction carried out by teacher } \\
\text { aides. }\end{array}$ & & & & \\
\hline $\begin{array}{l}\text { 20. Teacher aides should be informed } \\
\text { about the educational needs (e.g., } \\
\text { IEP goals and objectives; } \\
\text { components of the National } \\
\text { Curriculum) and } \\
\text { characteristics of the students with } \\
\text { whom they work, as well as } \\
\text { classroom and school practices and } \\
\text { routines. }\end{array}$ & & & & \\
\hline $\begin{array}{l}\text { 21. Teacher aides should have } \\
\text { opportunities to contribute to the } \\
\text { development of the educational } \\
\text { programme, instructional plans, and } \\
\text { activities created by each student's } \\
\text { educatlonal team, but should not be } \\
\text { given sole responsibility for these and } \\
\text { related activities. }\end{array}$ & & & & \\
\hline
\end{tabular}




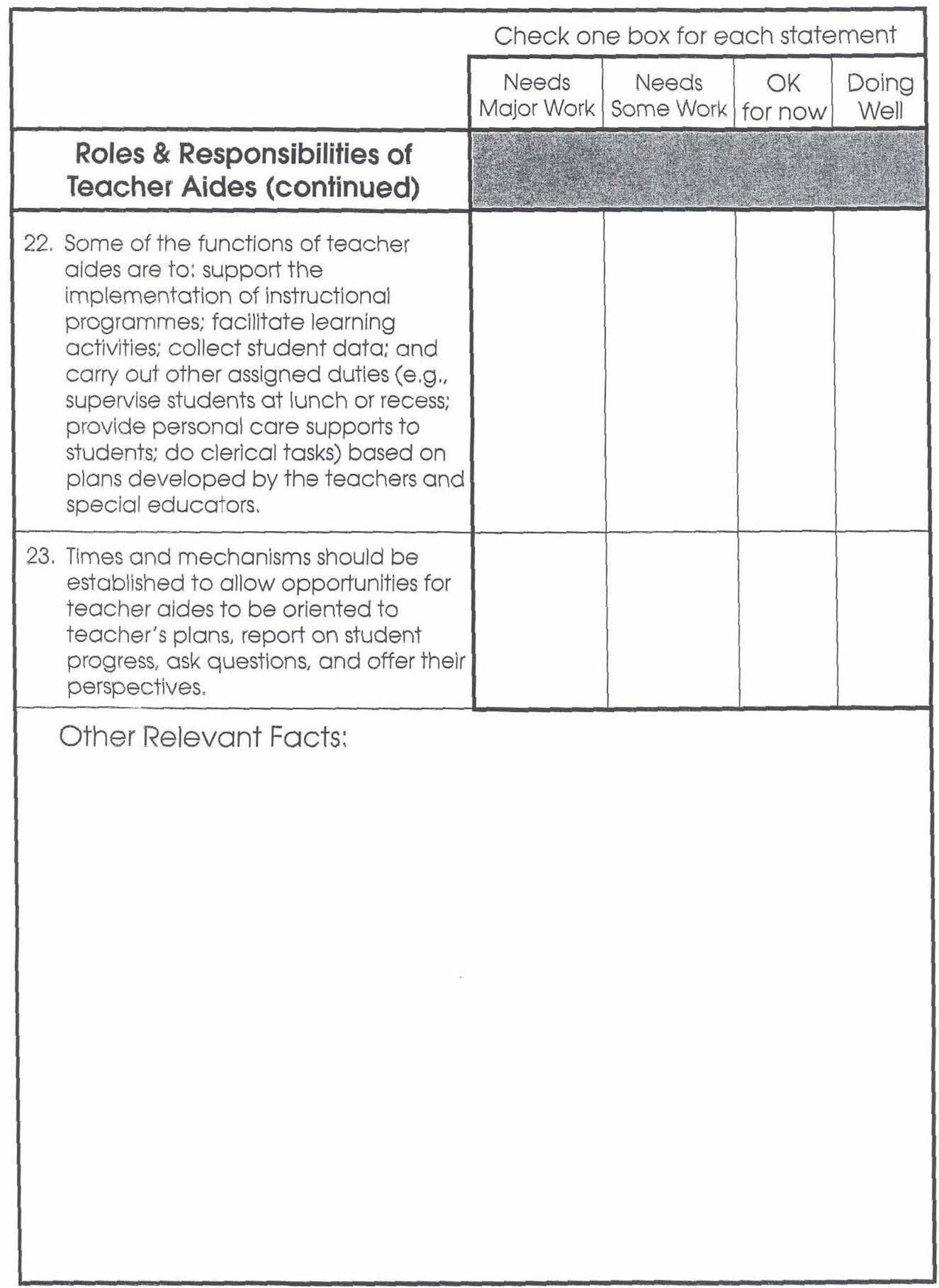




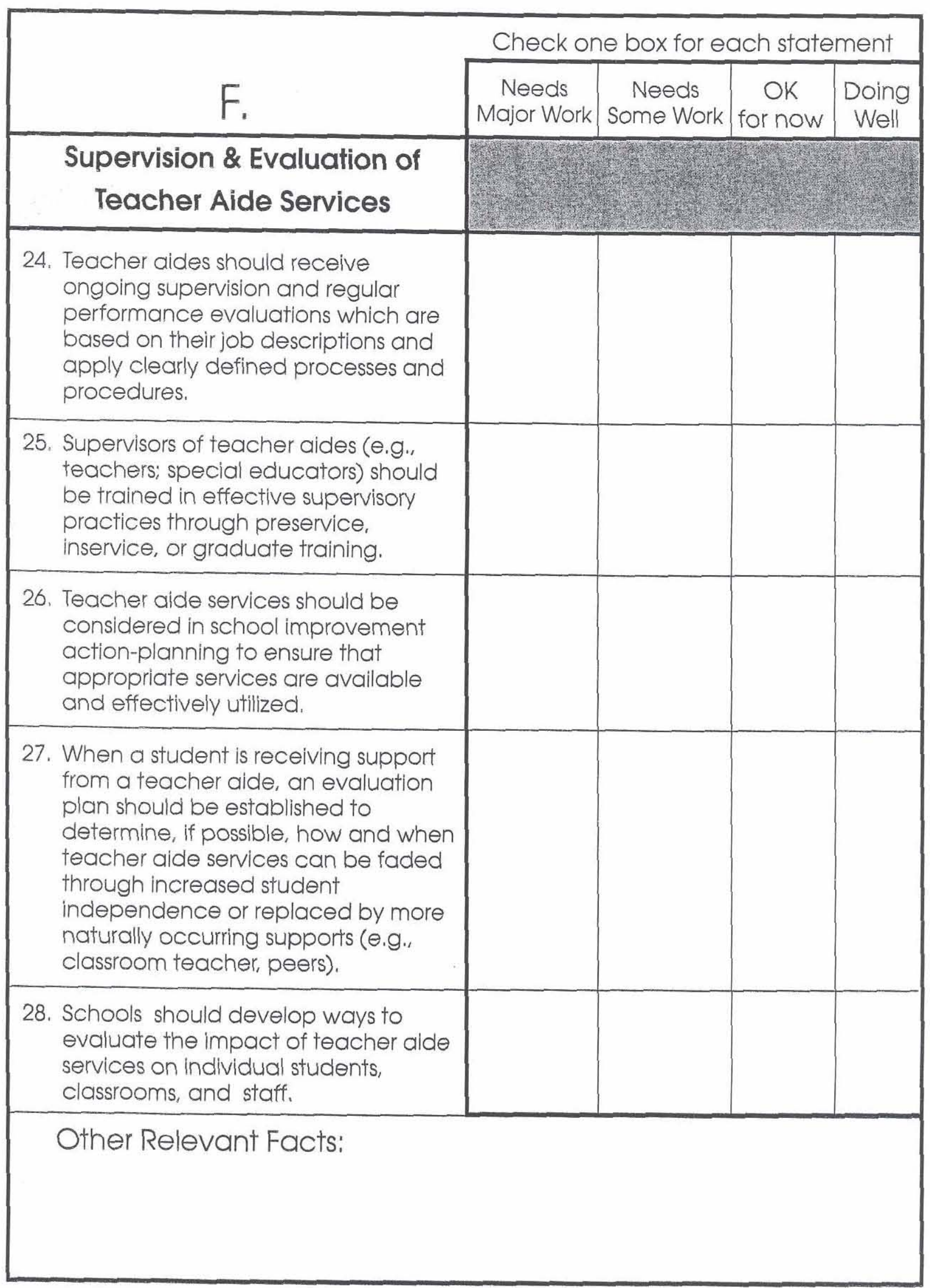




\section{Appendix B}

1. In what ways might we

\section{Brainstorming Worksheet}

2. List of Brainstormed Possibilities

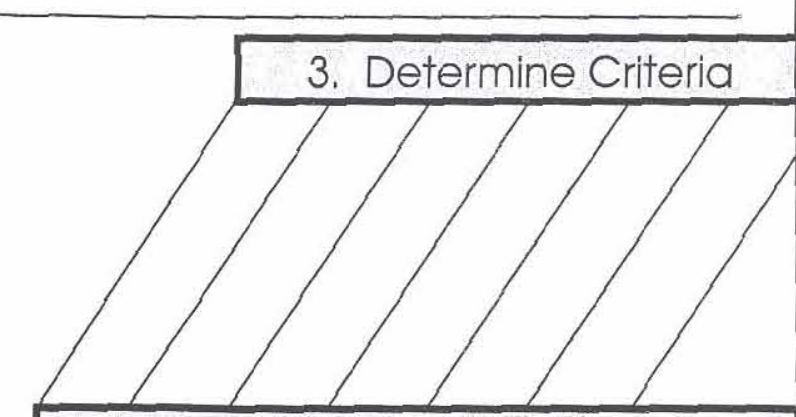

4. Evaluate Ideas Using Criteria

5. Select the ideas to Pursue (Indicate by circling) 


\section{Appendix D}
VICTORIA UNIVERSITY OF WELLINGTON
Te Whare Wananga o te Upoko o te Ika a Maui

\section{An investigation into teacher aide support.}

\section{INSTRUCTIONS}

Do not write your name on this sheet, instead record the participant code assigned to you by the researcher.

This is a confidential questionnaire and no individual responses will be identified in the final report.

Please answer all questions. If you wish to make further comments or clarify any response write under the question concerned.

Participant Code:

What is your position in regards to the teacher aide support planning team? (Please tick)

Teacher Aide

Teacher

Parent

Principal

RTLB

SENCO

Other (please specify)

Please record your response by circling a number from 1- 4 that best matches your thoughts.

\section{The teacher aide action planning process:}

1. helped me gain insights about teacher aide issues in our school.
1
2
3
4
Strongly disagree
Disagree
Agree
Strongly agree

2. helped me understand the perspectives of others about teacher aide issues.

$\begin{array}{llll}1 & 2 & 3 & 4 \\ \text { Strongly disagree } & \text { Disagree } & \text { Agree } & \text { Strongly agree }\end{array}$


3. helped our school select appropriate priorities that require attention.

$\begin{array}{llll}1 & 2 & 3 & 4 \\ \text { Strongly disagree } & \text { Disagree } & \text { Agree } & \text { Strongly agree }\end{array}$

4. helped our school develop an appropriate plan to address our self identified priorities

$\begin{array}{llll}1 & 2 & 3 & 4 \\ \text { Strongly disagree } & \text { Disagree } & \text { Agree } & \text { Strongly agree }\end{array}$

5. is an important activity for our school.

$\begin{array}{llll}1 & 2 & 3 & 4 \\ \text { Strongly disagree } & \text { Disagree } & \text { Agree } & \text { Strongly agree }\end{array}$

6. is a logical process.

$\begin{array}{llll}1 & 2 & 3 & 4 \\ \text { Strongly disagree } & \text { Disagree } & \text { Agree } & \text { Strongly agree }\end{array}$

7. is easy to use.

$\begin{array}{llll}1 & 2 & 3 & 4 \\ \text { Strongly disagree } & \text { Disagree } & \text { Agree } & \text { Strongly agree }\end{array}$

8. What do you perceive to be the strengths of this process? 
9. What do you perceive to be the weaknesses of this process?

10. Do you have any suggestions for improving the process so far?

Thank you for taking the time to complete this questionnaire. 


\section{Appendix E}

\section{VICTORIA UNIVERSITY OF WELLINGTON}

Te Whare Wananga o te Upoko o te Ika a Maui

Please fill in this questionnaire as fully as possible - your comments are important for this research. This questionnaire is anonymous.

\section{TEACHER AIDE QUESTIONNAIRE}

1.Were you given time to find out about the teacher, students and the class?
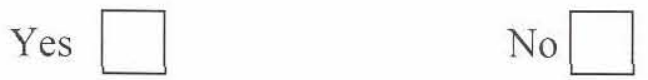

Comment

2.Did you feel able to collaborate?

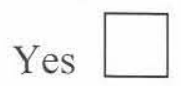

No

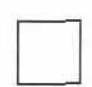

Comment

3. Did you feel informed about your role in the first weeks?

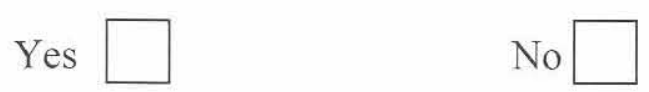

Comment

4. Are you clear about your roles and responsibilities?

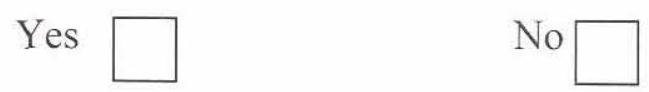

Comment

5. Do you feel that you have a good understanding of the students' needs?

Yes

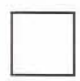

No

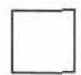


6. Do you feel familiar with classroom routines?
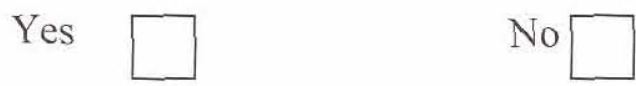

Comment

7. Do you feel comfortable with communication so far?

Yes

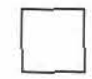

No

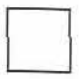

Comment

8. Do you feel informed about induction procedures?

Yes $\square$

No

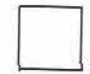

Comment

9. Do you feel informed about how to access information regarding training opportunities?

Yes $\square$

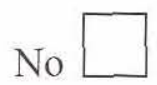

Comment

For returning teacher aides:

10. Do you feel more informed as a result of this process than in previous years?

Yes
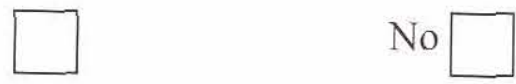

Comment

Thankyou for completing this questionnaire. Your input is really appreciated.

Please return to Bronnie by

\section{Mary Hancox}




\section{Appendix F}

VICTORIA UNIVERSITY OF WELLINGTON

Te Whare Wananga o te Upoko o te Ika a Maui

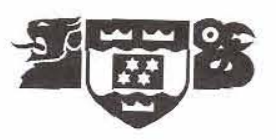

\section{An investigation into teacher aide support.}

Please answer these questions as fully as possible and bring the completed sheets with you to your interview. Thankyou for your input.

\section{Did use of the teacher aide action planning guide:}

1. Assist with clarification of roles and responsibilities between teacher aides and other school professionals?

2. Improve morale among teacher aides?

3. Increase awareness of teacher aide value amongst the school staff?

4. Improve student achievement?

5. Lead to better inclusion of all students?

6. Lead to a better understanding of the students? 
7. Improve delivery of instruction?

8. Improve home/school collaboration?

9. Increase peer interactions?

Thankyou again for taking the time to answer these questions. 


\section{Appendix G}

\section{Guidelines for Teacher Only Day}

Begin by having a 'getting to know you' session - this can be as informal as the parties feel comfortable with, and can include such sharing as family makeup and names, previous employment, favourite activities, hobbies etc. Discuss the following:

- Composition of the class using class lists.

- Classroom layout and seating plan for students.

- Synopses of students with IEPs (perhaps with some background notes on any identified needs e.g. visual impaired, hearing impaired).

- Teaching plan for the first two weeks of the year.

- Teacher expectations of the teacher aide in those first two weeks.

- Menu of activities or tasks that the teacher aide can usefully do if there is any 'down time' for him/her in the classroom.

- Process for when the teacher, teacher aide or particular students are absent.

- Methods of communication between teacher/teacher aide/parents or caregivers.

Introduce the agenda for the Week 3 meeting.

Set other meeting times for the term. 


\section{Appendix H}

\section{Teacher Aide Induction Checklist}

1. Principal's letter of employment - start, finish dates, rate of pay, hours per week, employment details as per collective employment contract, union information.

2. Meeting with executive officer re pay details, staff fund, holiday fund savings.

3. Introduction to students, parents and staff. Photo available for staffroom and family, if necessary.

4. Documents to new teacher aide for background reading - reports from other agencies on student, recent relevant data on student, school enrolment pack, Learning Support manual (clearfile), Behaviour management manual (clearfile), copy of duty rosters.

5. Tour of school and grounds with relevant commentary.

6. Meeting with Learning Support Coordinator to go through lines of communication (staffroom whiteboards, daily notices, staff meeting notes, senior staff meeting notes and roster, social club, pigeon holes, messages,' time in lieu' procedures, notification of absence, application for leave, staff manual, EOTC procedures.

7. Generic job description plus responsibilities of this particular job and health needs.

8. Timetable.

9. Time to observe in classes in which teacher aide will be employed.

10. Time to observe other teacher aides.

11. If replacing a current teacher aide then time to observe that person working, if possible.

12. Training programmes to be implemented from LSC \&/or classroom teacher, RTLB, SLT, GSE, itinerant teachers and advisers (on a case by case basis).

13. Bill Rogers videos.

14. Staff development opportunities and funding - see Curriculum Manager or LSC for details.

15. Desk and storage area for teacher aide.

16. Resources in and out of the school.

17. Computer access, email access. photocopier PIN, Web calendar password. 
Appendix I

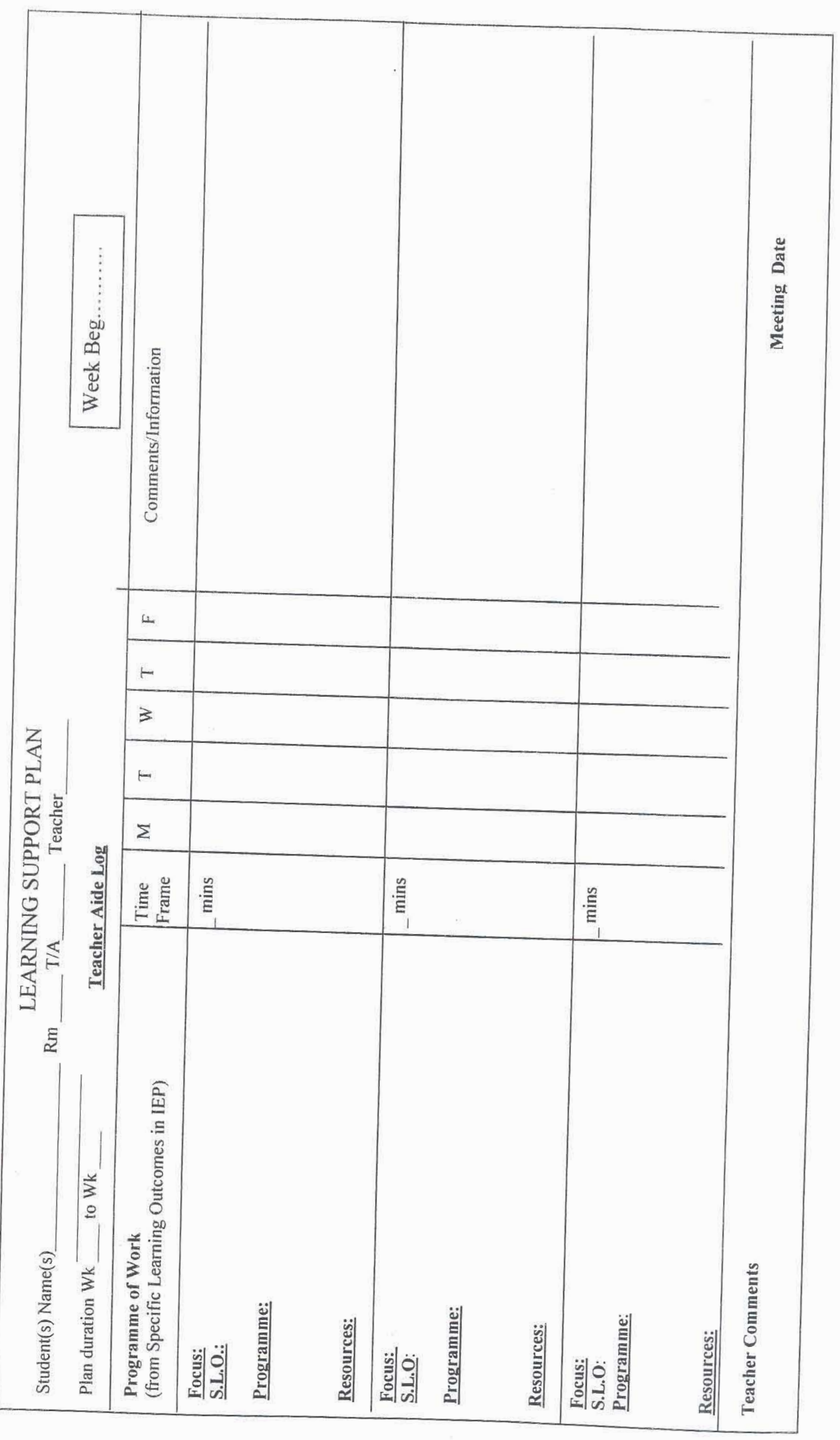




\section{Appendix $J$}

\section{VICTORIA UNIVERSITY OF WELLINGTON \\ Te Whare Wananga o te Upoko o te Ika a Maui

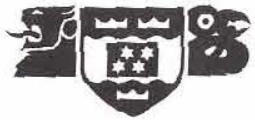

\section{Participant Information Sheet}

Researcher: Mary Hancox: Department of Education, Victoria University of Wellington.

I am a Masters student in Education at Victoria University of Wellington. As part of this degree I am undertaking a research project leading to a thesis. The project I am undertaking is the study of the use of a planning guide for teacher aide support in a school that has students with special education needs in general classrooms.

Your school community is invited to participate in this study. Participants will be asked to be part of a team, and using the planning guide will evaluate the school's position on a variety of issues relating to teacher aides. These issues will be prioritised and one or two selected to work on. Ideas will be generated and solutions planned and implemented. After evaluating the outcomes, participants will be asked to complete a questionnaire and take part in a semi structured interview to ascertain the efficacy of the process and its impact on students and the school community.

The expected time frame is one school year.

The team will be lead by me in my position as an RTLB. It is anticipated that there will be regular meetings throughout the year for the team to meet. These will be fortnightly in the first term, but will be less frequent in the subsequent terms.

Should any participants feel the need to withdraw from the project, they may do so without question at any time before the data is analysed and their data will be destroyed.

The data will be collected from the planning guide (which is in the form of a workbook), a questionnaire and interview, meeting notes and permanent products collected such as job descriptions, appraisal forms and weekly planning sheets.

The project will be written up as a report, but no school or personnel will be named. The material collected will be kept confidential. No other person apart from myself, my University supervisor, Charlotte Thomson and the tape transcribers will see the material collected. The thesis will be submitted for marking to the School of Education and deposited in the University Library. It is intended that one or more articles will be submitted for publication in scholarly journals. Guides, interview material and questionnaires will be destroyed two years after the end of the project.

If you have any questions or would like to receive further information about the project, please contact me at maryhancox@xtra.co.nz or my supervisor, Charlotte Thomson, at the School of Education at Victoria University, P O Box 600, Wellington, phone 044635937

Signed:

Mary Hancox

Resource Teacher Learning and Behaviour 


\section{Appendix K}

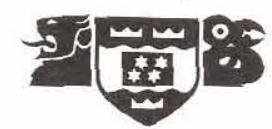

\section{CONSENT TO PARTICIPATE IN RESEARCH}

Title of project: An investigation into teacher aide support in an inclusive school.

I have been given and have understood an explanation of this research project. I have had an opportunity to ask questions and have them answered to my satisfaction. I understand that I may withdraw myself (or any information I have provided) from this project before data collection and analysis is complete without having to give reasons.

I understand that any information I provide will be kept confidential to the researcher, the supervisor and the person who transcribes the tape recordings of our interview, the published results will not use my name, and that no opinions will be attributed to me in any way that will identify me. I understand that the tape recording of interviews will be electronically wiped at the end of the project unless I indicate that I would like them returned to me.

Please return tape. $\mathrm{Y} \quad \mathrm{N}$ (circle)

I agree to take part in this research.

Signed.

Date

Name of participant.

Name of Researcher Mary Hancox 


\section{Plan of Action (1)}

Priority Idea: To make time on 'Teacher Only Day' for information sharing between teachers and teacher aides.

As a result of taking the actions listed below we hope the impact will include: $\mathbf{A}$ greater rapport between teachers and teacher aides and a better understanding of expectations in the early weeks of the school year.

What will be done?

- Principal to be approached with the above idea. By Whom?

When?

- Teacher aides to be consulted.

Deputy principal

Next senior staff

Teacher aide meeting.

representative.

Next teacher

Teacher aides to the

repres

aide meeting.

- Time allocated prior to lunch on TO day so that the teacher aides can have a social time with the rest of the staff.

Deputy principal and SENCO.

Planning session

for TO day.

- Guidelines written for the information sharing.

Teacher Aide

Support Team

Next team

meeting.

- Special conditions for teachers who have more than one teacher aide working in their rooms and for teacher aides

DP and SENCO. who are working with more than one teacher.

Planning session

for TO day.

Teacher Aide

- Evaluation questionnaire compiled.

\section{Evaluation: How will we tell if the implementation of our plan is having its intended impact?}

Questionnaire administered in Week 2 of Term 1 for teacher aides to:

1. Evaluate information sharing session on Teacher Only Day

2. Make comparisons (where possible) as to how the information sharing session made a difference to their start of the school year. 


\section{Plan of Action (2)}

Priority Idea: Special Education Needs Coordinator (SENCO) to release teachers in Week 3, Term 1 to meet with teacher aides.

As a result of taking the actions listed below we hope the impact will include: Clarification of roles and responsibilities, better understanding of students' needs and clearer communication.

\section{What will be done?}

- An agenda for the meeting compiled by both parties over Weeks 1 and 2 .

\section{By Whom?}

- Timetable of teacher release.

- Discussion of agenda items which will include:

- roles and responsibilities

- learning support plan

- methods of communication

- Special conditions for those teachers who have more than one teacher aide in their classroom and for teacher aides who work with more than one teacher,

Evaluation questionnaire compiled.
Teachers and

teacher aides

SENCO

When?

Weeks 1 and 2 , 2004

Week 1, 2004

Teachers and

teacher aides

SENCO, teachers

and teacher aides

Week 3, 2004

Teacher Aide

Support Team

Evaluation: How will we tell if the implementation of our plan is having its intended impact?

1. Questionnaire administered in Week 4 of Term 1 for teacher aides to evaluate Week 3 teacher and teacher aide meetings.

2. Evidence of permanent products, such as timetables, learning support plans, communication notebooks. 


\section{Plan of Action (3)}

Priority Idea: To update all teacher aides on the contents of the teacher aide induction checklist and relevant manuals.

As a result of taking the actions listed below we hope the impact will include: teacher aides being better informed on induction procedures and training opportunities available.

What will be done?

Current teacher aide induction checklist updated.

By Whom?

Inclusion of this checklist and how to access training opportunities into in the staff manual.

Teacher aides given a copy of the checklist and alerted to the location of the staff (and other) manuals - Room 14.

New and current teacher aides and teachers to discuss needs (if any) at the meeting during 'Teacher Only' day (Term 1 2004).

Evaluation: How will we tell if the implementation of our plan is having its intended impact?

Add questions to the teacher aide questionnaire to ascertain whether teacher aides feel more informed on:

a) induction procedures

b) training opportunities

SENCO

DP

When?

End Term 3

Term 42003

SENCO and TA

rep

Term 4

2003/Term 1

2004

All staff 